\title{
ESPAÇOS ABERTOS E ESPAÇOS LIVRES: UM ESTUDO DE TIPOLOGIAS
}

\author{
URBAN OPEN SPACES: A TIPOLOGY STUDY
}

\author{
Evy Hannes*
}

\section{RESUMO}

Este artigo apresenta uma discussão referente às tipologias de espaços abertos e de espaços livres, conceituando-os brevemente e colocando questões relativas às esferas pública e privada. Discute suas diferentes funções nas áreas urbanas, ressaltando as de caráter urbanístico, social, recreativas, estético e ecológico. Tem como objetivo elencar os principais espaços livres de uso público na escala urbana da cidade existentes no Brasil, definindo-os, fazendo referência ao seu surgimento na história, evolução no contexto urbano, usos e desenho. Serão analisados autores que percorrem as diversas facetas do urbano, como a morfologia urbana, a história, percepção, memória e apropriação do espaço.

Palavras-chave: Espaços livres. Espaços abertos. Espaço público. Tipologia de espaços abertos. Esfera pública.

\section{ABSTRACT}

This article presents a discussion related to urban open space typology, briefly conceptualizing it and reviewing the issues related to public and private spheres. It discusses their different functions in urban areas, highlighting the urbanistic, social, recreation, aesthetic and ecological character. It aims to list and describe the various types of open spaces in Brasil, at the city scale, referring to its appearance in the history, evolution in the urban context, uses and design. An analysis of the authors, dealing with various facets of urban contents as urban morphology, history, perception, memory and appropriation of space, will be made.

Keywords: Open spaces. Public space. Open spaces typology. Public space realm.

\section{INTRODUÇÃO}

Este trabalho pretende discutir questões relacionadas aos espaços livres urbanos, elencando as tipologias mais presentes ou que mais se adequam à utilização nas escalas do bairro e da cidade. Serão abordadas as tipologias da rua, principal espaço livre presente nas cidades, estruturador e articulador do espaço urbano, canal primeiro de circulação e trocas; o calçadão, que se apresenta como rua exclusiva para pedestres,

\footnotetext{
Arquiteta e urbanista, especialista em Arquitetura da Paisagem e Desenho Ambiental pela Universidade Presbiteriana Mackenzie (UPM). Mestranda da área de concentração Paisagem e Ambiente do Programa de Pós-Graduação em Arquitetura e Urbanismo da Faculdade de Arquitetura e Urbanismo da Universidade de São Paulo (FAUUSP). Docente de Projeto Urbano e Paisagismo na Universidade Paulista (UNIP).

evyhannes@yahoo.com
} 
sendo uma tipologia bastante presente e aceita no Brasil; o woonerf, apresentado como um tipo relativamente novo de espaço livre, ainda não tão presente no país - mas com grande potencial de aplicação -, que vem sendo muito trabalhado nas faculdades de arquitetura; o pátio também apresenta interessante característica de espaço, muitas vezes privado, mas com forte potencial de apropriação pública e articulação entre público e privado; a praça, espaço público de encontro por excelência, presente em cidades dos mais variados tamanhos, apresentando modelos tão diversos e, muitas vezes, distantes de seu conceito principal; o pocket parque, o segundo elemento ainda não muito presente nas cidades brasileiras, mas que vem ganhando força como intervenção pontual na cidade de São Paulo, que demonstra o enriquecimento do espaço aberto e grande aceitação e apropriação por parte do público; por último, coloca-se - parque urbano como elemento de caráter natural, com grande potencial de usos ligados a lazer e esportes.

Os temas e elenco de tipologias analisados foram escolhidos devido à ausência de trabalhos acadêmicos que os coloquem conjuntamente. Grande parte dos trabaIhos disponíveis percorre apenas modelos mais tradicionais, como a rua, a praça e o parque. Outros apontam os elementos separadamente, em trabalhos de conteúdo rico e detalhado, mas muito extensos. Essa lacuna foi percebida diante da dificuldade de indicar aos alunos ingressantes nos estudos de projeto urbano e paisagismo apontamentos bibliográficos que funcionem como base teórica introdutória ao tema, sem que fosse necessário recorrer a um número extenso de publicações que o abordam sob diferentes focos, dificultando o entendimento do assunto. Este trabalho faz parte de um projeto de pesquisa que vinha sendo idealizado desde 2013 e que se inicia com o desenvolvimento deste artigo.

Para o desenvolvimento da análise pretendida, serão abordados diferentes aspectos relativos aos espaços livres e os autores mais conceituados em relação ao tema. Na conceituação deste, das esferas pública e privada e da apropriação dos espaços livres, serão utilizados estudos de Queiroga (2012), Magnoli (1982), Arendt (1991) e Habermas (1984). A análise morfológica será orientada pela obra de Lamas (1993). Para as questões ligadas à imagem e leitura dos espaços, serão utilizados conceitos de Lynch (1997) e Cullen (1983); para entendimento da apropriação dos espaços, Gehl (2013) e Jacobs (2000); para estudo do desenho dos espaços, Santos (1988); para entendimento de áreas ligadas a questões naturais, como praças e parques, Macedo (1999, 2003, 2011) e Kliass (1993).

\section{ESPAÇOS LIVRES, ESFERA PÚBLICA E ESFERA PRIVADA}

A conceituação de espaços livres é relativamente simples, mas ampla e consideravelmente congruente no meio acadêmico quando aborda questões relativas ao espaço público e ao privado. Magnoli (1982) define espaço livre como qualquer espaço livre de edificação ou de urbanização e como espaços destinados ao trabalho dos arquitetos paisagistas. Podem, também, ser chamados de espaços abertos, e representam os 
espaços livres de um volume edificado, sendo estes públicos ou privados, como ruas e calçadas, parques e praças, quintais residenciais, áreas livres de lazer em condomínios, recuos de construções, pátios internos, estacionamentos descobertos, terrenos baldios, rios, áreas verdes e outros.

Toda cidade tem um sistema de espaços livres, e esses espaços são fruto do processo de urbanização e formação. (MACEDO, 2011). O parcelamento do solo, as construções e o arruamento dão origem a inúmeras tipologias de espaços e diversas formas de apropriação das mesmas. Tendo ou não sido criados para uso específico como os calçadões, que permitem melhor circulação de pedestres por vias densas de comércio - o espaço livre, ou aberto, torna-se palco para diversas formas de expressão da sociedade. São espaços de encontro, lazer, práticas esportivas e manifestações. Como colocado por Leite:

[...] é a possibilidade de entrar em contato com uma extensa diversidade de situações e pessoas o que define a urbanidade, sugerindo, para que tal espaço possa operar uma atividade pública, que ele permita, em primeiro lugar, a copresença de indivíduos, fato intrinsecamente relacionado às condições de sua formação. (SORRE apud LEITE, 1984, p. 2).

O termo espaço livre, muitas vezes, é confundido ou usado erroneamente para denominar espaços públicos. $\bigcirc$ mesmo também acontece quando um espaço de propriedade particular é tido como público devido à sua apropriação. Queiroga (2012), em sua tese de livre docência, utilizada como embasamento teórico para o desenvolvimento deste capítulo, coloca a necessidade de conceituar e diferenciar os termos espaço público e esfera pública, desenvolvendo ampla discussão sobre o assunto e apontando a fragilidade do termo espaço público. Neste artigo, serão sintetizados, brevemente, os conceitos de propriedade pública e privada do espaço, esfera da vida pública e esfera da vida privada, sem prolongar a discussão acerca da definição dos termos espaço e esferas da vida, para que a diferenciação entre as expressões seja esclarecida sinteticamente ao leitor ou pesquisador iniciante.

Queiroga (2012) credita à Arendt (1991) a primeira construção dos conceitos de esfera de vida pública e privada. A autora entende a esfera pública como a esfera de vida correspondente às ações humanas (políticas). Habermas (1984) relaciona a esfera pública às relações da sociedade, à comunicação e às discussões políticas. Segundo Queiroga (2012, p. 46): "[...] para Habermas, a esfera pública é o espaço do trato comunicativo de uns com os outros". Dessa forma, pode-se entender como esfera pública todo espaço onde se dão as relações da sociedade, o convívio público; todo espaço onde as pessoas se encontram, onde acontecem as manifestações coletivas humanas. Tais acontecimentos independem do tipo de propriedade do espaço em que ocorrem, podendo acontecer em espaços públicos ou privados.

Sobre a esfera privada, Arendt (1991) enfatiza sua ligação com a família, enquanto Habermas acredita que ela corresponde "[...] ao reino das necessidades e das transi- 
toriedades [...]", visando a interesses privados. (HABERMAS, 1984 apud QUEIROGA, 2012 , p. 41). Fica clara, então, a relação entre a esfera privada e os interesses privados dos cidadãos, e não da coletividade.

Espaço de propriedade privada é aquele que pertence a uma pessoa física ou instituição, podendo ser aberto ou não ao uso do público. Como exemplos de espaços abertos privados podemos citar: quintais residenciais, pátios escolares, campos de futebol particulares, áreas de lazer de condomínios, jóquei clubes e outros. São espaços fragmentados, de tamanho e composição muito diversificados. Os quintais residenciais são espaços de grande valor ambiental e paisagístico para a cidade, mas sofrem constante transformação, perdendo esse potencial, já que frequentemente são transformados em áreas cimentadas e cobertas, dando lugar a vagas de garagem e edículas. (MACEDO, 1999, 2011).

Espaço público é aquele de uso comum, de propriedade pública. Eles podem ser abertos e de livre acesso ao público, como as vias de circulação e áreas de lazer - praças, parques e praias. Também podem ter acesso restrito ao público em geral, como prefeituras, fóruns, instituições de ensino e hospitais. Queiroga denomina como espaço público:

Todo aquele de propriedade pública, podendo se prestar ou não à esfera pública [...]. Não se abre mão em designar como espaço público uma série de espaços de propriedade pública que interessa assim serem caracterizados e chamados - espaços públicos - salvaguardando sua natureza pública (de todos), ainda que não sejam necessariamente espaços da esfera pública. (QUEIROGA, 2012, p. 58).

É importante ressaltar que espaços de propriedade privada podem ser de grande interesse e apropriação pública e correspondentes à esfera pública da vida, como é o caso dos estádios de futebol, universidades, parques temáticos e espaços livres de edificações privados, como a praça do Brascan Century Plaza, no bairro do Itaim, São Paulo, que possibilita a apropriação do espaço em determinados horários e com certas restrições de uso. $\bigcirc$ quintal da Casa das Rosas, localizado na avenida Paulista em São Paulo, que oferece, além da passagem entre a alameda Santos e a avenida Paulista, espaços para descanso e até para café ou almoço nas mesas do restaurante que se localiza em seu interior, também se enquadra nessa categoria, bem como a praça sob o vão do Museu de Arte de São Paulo (MASP), com sua tradicional feira de antiguidades. Todos esses espaços servem de exemplo para o que Queiroga denomina espacialidades da esfera pública (QUEIROGA, 2012), que caracterizam os espaços onde se praticam atividades em sociedade.

\section{FUNÇÕES DOS ESPAÇOS LIVRES}

Os espaços livres desempenham outros papéis, independentes de suas funções características, principalmente no que diz respeito à melhoria do ambiente excessivamente 
impactado pela urbanização das cidades. Entre essas funções, ressalta-se neste trabalho as consideradas de maior relevância, como as funções ecológicas, estéticas e sociais.

A função ecológica caracteriza-se pela presença de vegetação e solo não impermeabilizado, ou que permita algum grau de drenagem e percolação das águas de chuva. O solo drenante ajuda a prevenir enchentes e contribui com a recarga do lençol freático. A vegetação também ajuda a combater enchentes - na medida em que as copas das árvores diminuem a velocidade com que a água atinge o solo - a filtragem do ar, a equilibrar a temperatura e umidade do ar, combatendo ilhas de calor e exercendo importante papel como suporte de movimento da avifauna.

A função social está intimamente relacionada às características ligadas ao convívio em comunidade e ao lazer. São espaços onde acontecem os encontros e trocas da vida cotidiana, desde os mais simples, como conversas entre amigos, até expressões culturais diversas - manifestações e apresentações ao ar livre. São espaços utilizados para lazer, descanso, leitura, meditação, orações, para o brincar das crianças e esportes das mais variadas modalidades. Possuem, também, importante função estética, encarregando-se da diversificação da paisagem construída e do embelezamento da cidade. Atuam como integradores entre espaço construído e aberto, muitas vezes tendo a função primeira de criar áreas para observação de obras arquitetônicas e permitir que estas sejam observadas e admiradas por melhores ângulos e nas devidas proporções. Os espaços vegetados têm papel especial na questão estética, iá que o colorido das árvores e sua mudança conforme as estações do ano acrescentam um toque especial à composição da paisagem.

\section{TIPOS DE ESPAÇOS LIVRES}

Existem dezenas (se não centenas) de tipos de espaços livres: alguns desenhados pelo homem; outros, pela natureza. Considerando os espaços livres como os que não são construídos, abertos, de livre acesso ou não à população, pode-se qualificar nessa categoria todo o espaço natural constituído por rios, praias, mares, matas e florestas. Como espaços desenhados pelo homem pode-se citar desde os campos de futebol desenhados com cal em terrenos baldios até os parques mais elaborados por equipes de arquitetos e ecólogos - mirantes, jardins, conjuntos esportivos, cemitérios, campi universitários, unidades de conservação ambiental, parques, praças, ruas, calçadas.

Neste trabalho serão abordados apenas os espaços livres urbanos mais comuns e presentes no Brasil e outros, ainda não tão difundidos aqui, mas que apresentam grande potencial para tal, criando espaços inovadores e ricos. São eles: ruas, calçadões, woonerfs, pátios, praças, pocket parks e parques.

\subsection{A RUA}

A rua é o elemento de estruturação mais importante do tecido urbano, pois, como via de circulação principal de pedestres, ciclistas e veículos, promove a articulação entre 
os demais componentes da malha urbana. Muitos autores estudaram e trabalharam em diferentes definições desse elemento, cada um na sua área de estudo, desde a morfologia até a paisagem urbana. Entre eles, destaca-se Lynch (1997), que a coloca como um dos diversos tipos de vias existentes na cidade, classificando-a como "[...] canais de circulação ao longo dos quais o observador se locomove de modo habitual, ocasional ou potencial". O autor também destaca o valor atribuído às que apresentam caráter individualizado, devido à concentração de certos tipos de atividades, como nos casos, em São Paulo, das ruas 25 de Março, José Paulino e Augusta.

Quando abordada do ponto de vista morfológico, por Lamas (1993), é vista como o elemento mais claramente identificável na forma da cidade, funcionando como reguladora entre edifícios e quadras e de suma importância na orientação dos pedestres. Santos (1988) aborda outros valores relativos à rua e destaca:

[...] ruas e elementos urbanos assemelhados (avenidas, travessas, ladeiras) são os espaços públicos, abertos, que servem à circulação entre dois renques de edificações. [...] Servem para ligar os diversos pontos de interesse particular ou semipúblico, conformando uma rede de canais livres e de propriedade coletiva. Se não existissem, não haveria troca de espécie alguma [...] são o palco onde se desenvolvem os dramas e representações da sociedade. Aí acontecem desde a agitação de todos os dias até as celebrações especiais: as procissões, a parada de Sete de Setembro, o carnaval [...] (SANTOS, 1988, p. 91).

Jacobs (2000) entende que as ruas e calçadas têm funções que vão muito além da circulação: são os órgãos vitais das cidades e conformam seu principal espaço público. Consagra a conhecida expressão os olhos da rua, referindo-se ao fator de segurança existente nas ruas onde o comércio está presente, onde os proprietários desses estabelecimentos e os pedestres que circulam entre eles, ao ocuparem as calçadas, agregam a estas movimento e segurança.

Gehl (2013, p. 19) prega a ideologia das cidades mais humanas, vivas, seguras, sustentáveis e saudáveis, e coloca como "[...] pré-requisito para a existência da vida urbana a oferta de boas oportunidades para se caminhar [...]", abordando, novamente, a rua como foco primário de configuração do urbano.

Entende-se, então, que a rua é o elemento estruturador do espaço urbano, com papel primário de circulação e orientação, que garante a ligação entre os demais espaços abertos da cidade, funcionando como articuladora de um sistema de espaços livres. É o principal palco da vida cotidiana, permitindo encontro, troca e diversas manifestações populares (figuras 1 e 2). É lugar carregado de simbolismo, espaço de permanência, de brincar, socializar, de aprendizado para crianças e jovens. Estabelece a conexão entre o público e o privado, sendo de vital importância para o desenho da cidade. Seu desenho deve ser cuidadoso e atento, apresentando dimensões adequadas aos usos a que se propõe, garantindo conforto, segurança e acessibilidade a pedestres, ciclistas e veículos, com fluxos organizados, respeitando normas técnicas, utilizando materiais corretos e eficazes, com arborização e iluminação corretamente especificadas e dimensionadas. 


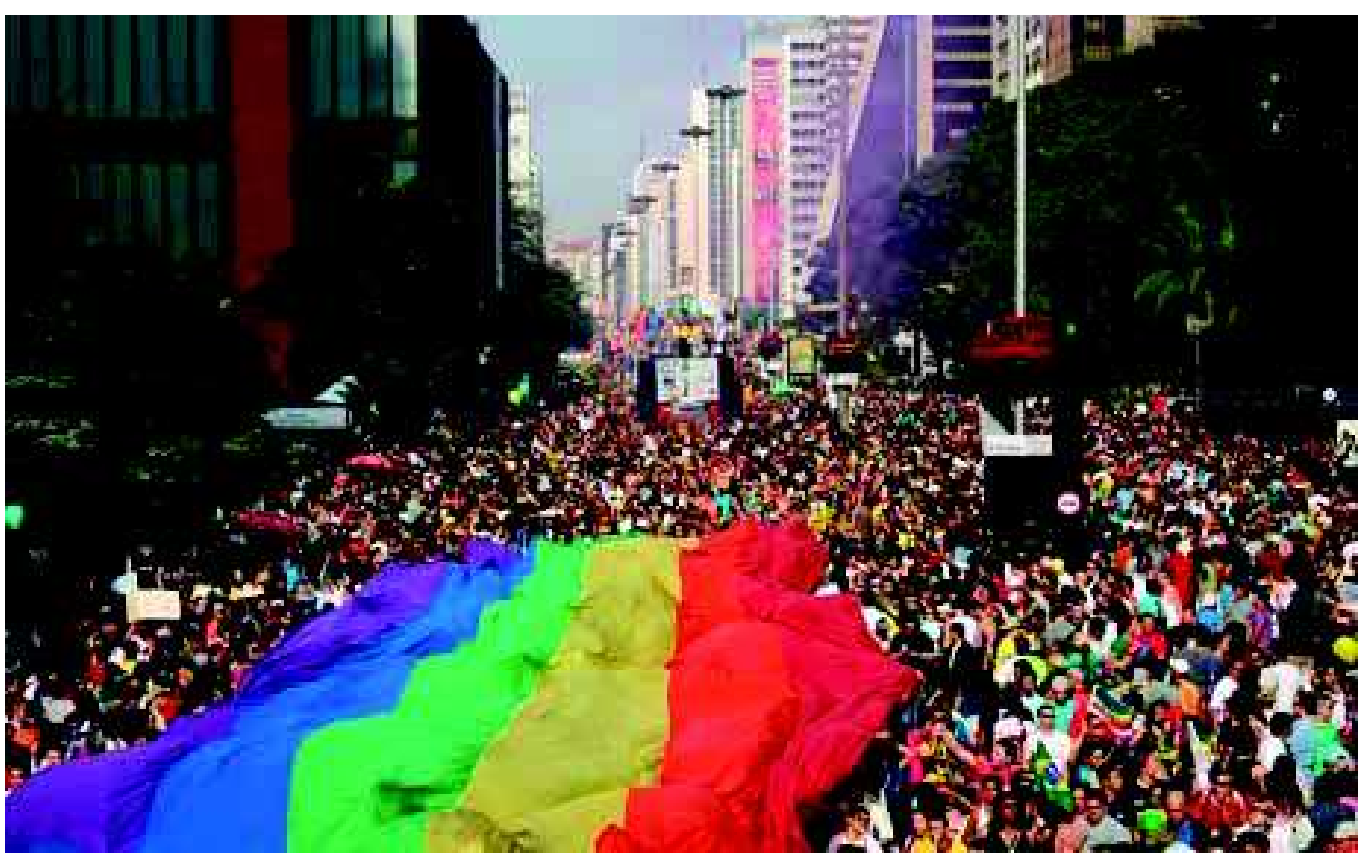

Figura 1 Parada Gay na avenida Paulista, São Paulo, SP.

Fonte: Fashion Bubbles. Disponível em: <http://www.fashionbubbles.com/bubbles/parada-lgbt-de-sao-paulorealiza-concurso-cultural-para-escolha-do-tema-da-proxima-edicao/>. Acesso em: 26 set. 2015.

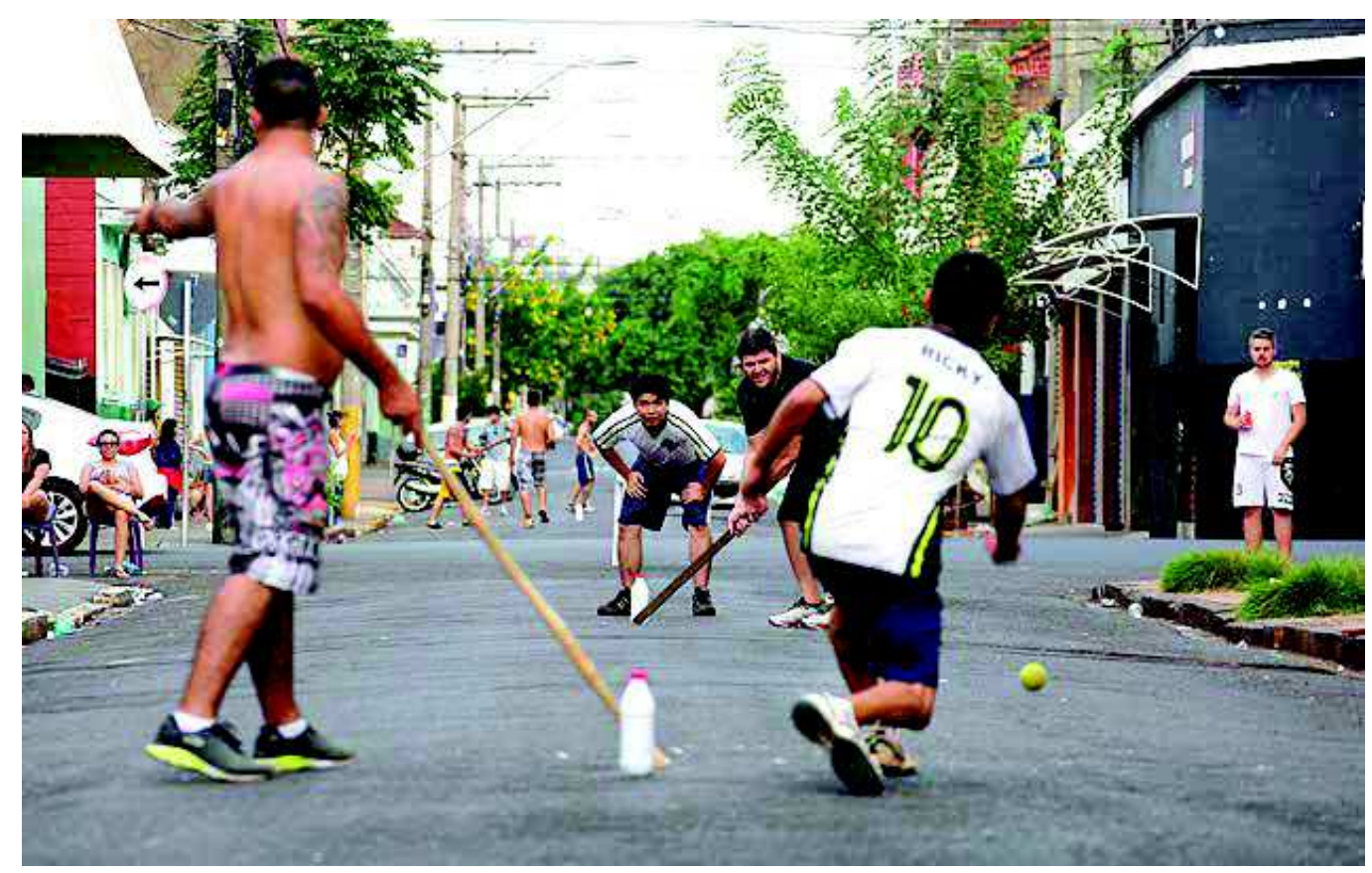

Figura 2 Jogo de taco na rua em Ribeirão Preto, SP.

Fonte: Folha de S. Paulo. Disponível em:<http://wwwl.folha.vol.com.br/cotidiano/

ribeiraopreto/2014/06/1463244-torneio-resgata-brincadeira-de-rua-no-centro-de-ribeirao-preto.shtml>. Acesso em: 26 set. 2015. 


\subsection{A RUA DE PEDESTRES - CALÇADÃO}

O termo calçadão tem sido usado no Brasil para definir as ruas exclusivas de pedestres. Os primeiros registros de que se possui notícia sobre o tema datam do período entre guerras, quando algumas ruas alemãs são fechadas para o tráfego de veículos. Em 1951, são projetadas as ruas Holstenstrasse e Kortumstrasse, ambas na Alemanha, e desde então a prática foi crescendo e consolidando-se, principalmente após a década de 1970, com a explosão da frota automotiva mundial e a necessidade de reorganização entre o fluxo de automóveis e pedestres. No Brasil, o primeiro calçadão construído foi o da rua XV de Novembro, ou calçadão das flores, em Curitiba (PR), como mostra a figura 3. (JANUZZI, 2006). São Paulo (SP) apresenta a maior rede de calçadões do país. Localizados na área central da cidade, fazem a ligação entre importantes equipamentos urbanos e são servidos por estações de metrô.

Os projetos de implantação de ruas de pedestres têm início, em sua maioria, com o fechamento do tráfego para veículos na via. Na sequência, são feitas reformas de nivelamento de piso, troca de pavimentação, paisagismo e adequação de mobiliário urbano. Segundo Januzzi (2006, p. 108), "[...] o modelo mais comum é o que se assemelha a um shopping center, com a adição de equipamentos para dar mais conforto ao usuário e tornar o espaço mais agradável, buscando renovação do centro urbano."

O uso dessa tipologia de espaço está comumente associado aos núcleos de comércio dos centros urbanos, onde o fluxo de pessoas e as atividades comerciais são intensas e apresentam conflitos de fluxos entre automóveis e pedestres. Tornam-se, geralmente, importantes centros de compras e pontos turísticos - como a Stiklal Street (Istambul), que, devido à sua grande extensão (3 quilômetros), implantou um bonde que facilita a locomoção dos pedestres (figura 4). Muitos projetos de calçadões fazem parte de operações de revitalização urbana que incluem renovação de fachadas, eliminação da polvição visual e melhoria na qualidade do espaço. São espaços que permitem a implantação de feiras de artesanato, a expressão de artistas de rua, o favorecimento de interação social, incentivando, também, o consumo e a diversificação de uso local. Devem prever o acesso de veículos de segurança e carga e descarga - como carros de polícia, ambulância e bombeiros.

Gehl (2013) ressalta a transformação na qualidade urbana da cidade de Copenhagen (Dinamarca) quando algumas ruas se tornaram exclusivas para pedestres "[...] era mais confortável para caminhar e havia espaço para mais gente" e coloca a "[...] melhoria sistemática da vida urbana e a movimentação de pedestres" como pontos positivos associados ao projeto.

Algumas variações do modelo padrão de ruas de pedestres permitem o tráfego controlado de veículos, como é o caso da Third Street Promenade, em Los Angeles, Califórnia. Outras apresentam cobertura, propiciando o uso independente de condições meteorológicas. Calçadões de praia e orlas marítimas são considerados tipologias diferenciadas, que mais se encaixam no conceito de mall e promenade, já que apre- 
sentam função e vocação diferenciadas, prestando-se ao passeio descompromissado, à observação da paisagem e às práticas esportivas.

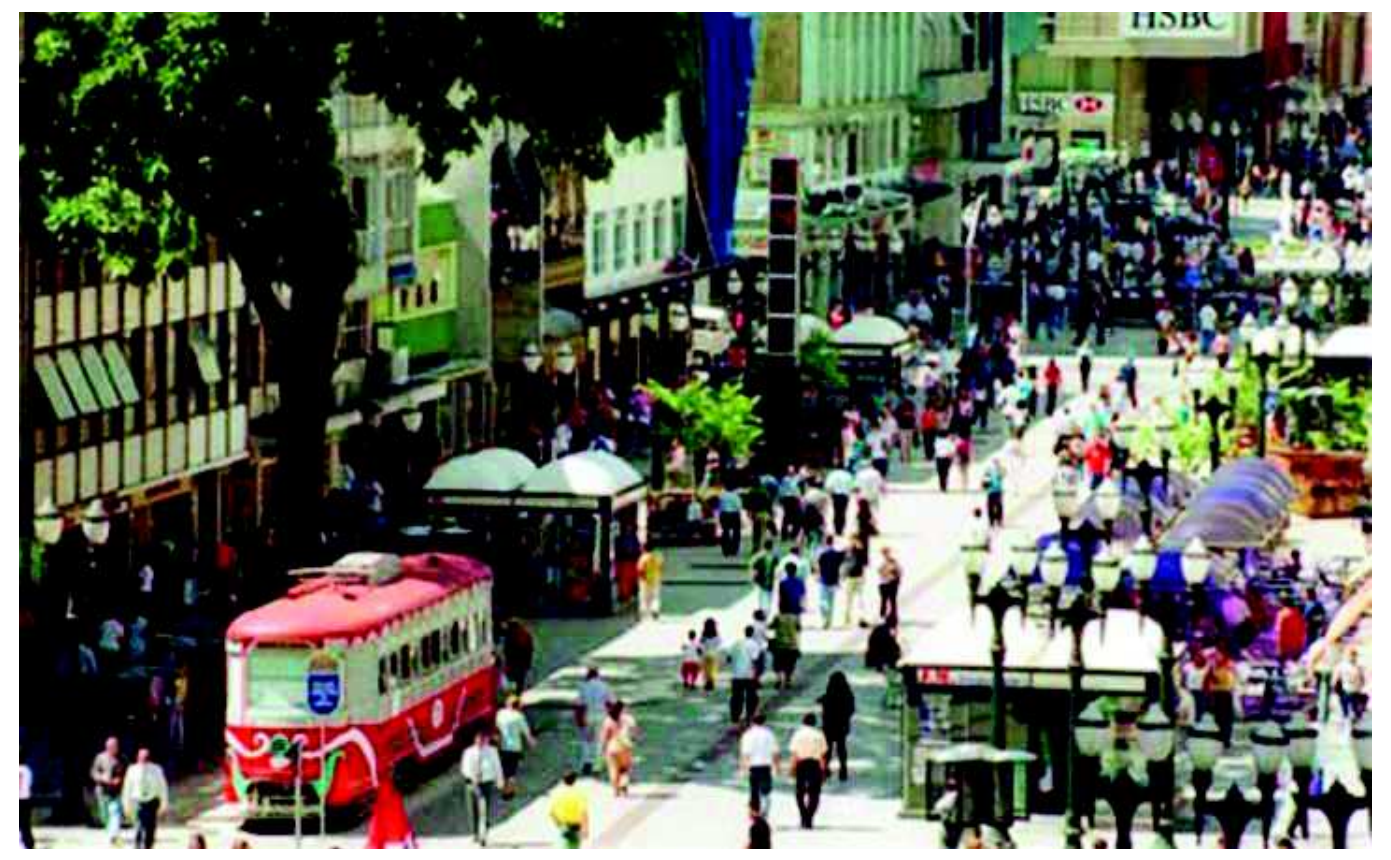

Figura 3 Rua XV de Novembro, a rua das flores, em Curitiba, PR.

Fonte: Guia geográfico da cidade de Curitiba. Disponível em: <http://curitiba.paises-america.com/bairros. htmconcurso-cultural-para-escolha-do-tema-da-proxima-edicao/>. Acesso em: 26 set. 2015.

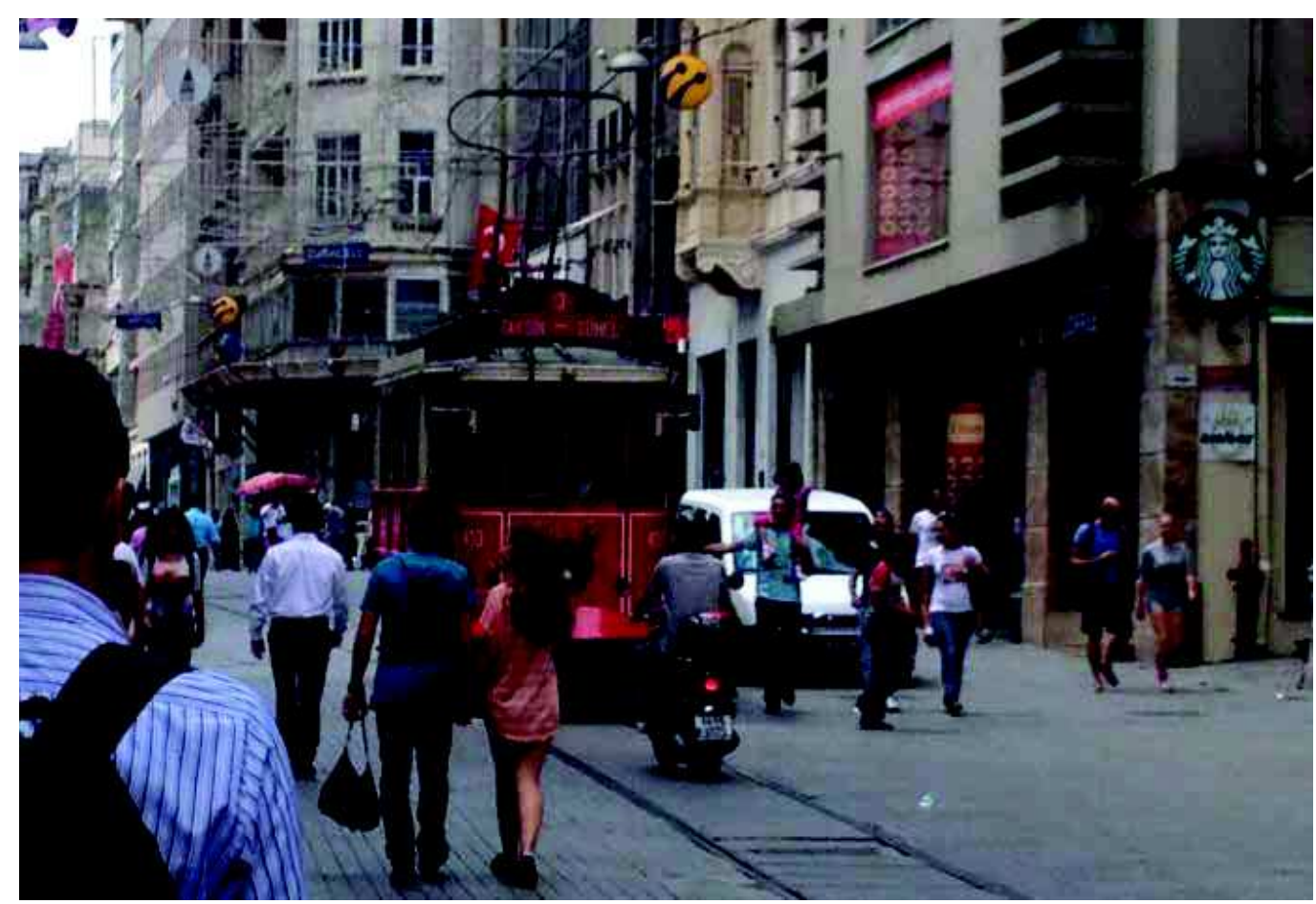

Figura 4 Rua Istiklal, em Istambul, Turquia.

Foto: Evy Hannes, jul. 2013. 


\subsection{O WOONERF}

Woonerf é um conceito holandês surgido na década de 1970 e significa rua viva ou quintal vivo. Muito popular na Europa e nos Estados Unidos, vem sendo utilizado com o nome de ruas completas, e, no Brasil, tem sido abordado com o nome de ruas compartilhadas. Trata-se de uma rua, ou quadra, onde pedestres, ciclistas e automóveis convivem em harmonia sem a necessidade do desenho normal que separa leito carroçável e passeio por meio de guias em desnível. É aplicado em ruas locais, sem semáforos e sem sinalização de trânsito, uma vez que sua ideia imprime cautela e cooperação por parte dos usuários. Apresenta medidas relativas a traffic calming, ou atenuantes de tráfego, como desenho curvilíneo do espaço, onde carros e bicicletas podem transitar, ou a colocação de canteiros e vasos no percurso, forçando os veículos a diminuir sua velocidade. É utilizado como quintal comunitário, contando com áreas para mobiliário fixo e móvel, áreas para as crianças brincarem e para o convívio social, como se vê na figura 5. Seu principal objetivo é promover segurança e qualidade de vida aos moradores, criando locais humanos e agradáveis onde os usuários convivem sem separação e em igualdade de direitos.

Desde seu surgimento, o conceito evoluiv e passou a ser adotado em áreas centrais como alternativa aos calçadões, criando áreas prioritárias para pedestres - onde veículos são permitidos apenas com controle da velocidade -, estacionamento e cuidados especiais onde há travessia de pedestres. A figura 6 mostra um exemplo dessa tipologia na rua Avanhandava, na cidade de São Paulo. O Vale do Anhangabaú também configura um exemplo de espaço onde pedestres e veículos convivem em harmonia, eliminando o uso do meio fio, já que foi projetado como espaço para uso prioritário de pedestres.

\subsection{O PÁTIO}

O conceito de pátio surgiu devido à necessidade do homem de estar em contato com o exterior e, ao mesmo tempo, proteger-se do mesmo, que era considerado hostil. Trata-se de uma abertura no seu espaço de proteção, de onde podem ser capturados trechos de paisagem. São encontrados pátios na arquitetura de diversas civilizações ao longo há história da humanidade. Nas construções do Império Assírio, desde o ano 540 a.C., como grandes espaços internos aos templos. Nas edificações residenciais greco-romanas aparecem como reservados espaços internos, com uso voltado para serviços diversos e desenvolvendo, posteriormente, usos referentes ao estar, onde eram cultivados flores e frutos. Na arquitetura do Oriente Médio, assumem papel importante, relativo a questões bioclimáticas, apresentando-se como espaços abertos necessários à ventilação e onde foram acrescentados, com o passar dos anos, espelhos d'água e fontes que refrigeravam os ambientes. Adquirem, nesse momento, importante valor estético e paisagístico. Na cultura asiática, aparecem como espaços para meditação, elevação espiritual e contato com a natureza em residências e grandes templos (figura 7). Nas construções religiosas da Idade Média, criadas sob influência da arquite- 
tura moura, representam espaços de quietude, oração e contemplação. (JELLICOE; JELLICOE, 1995).

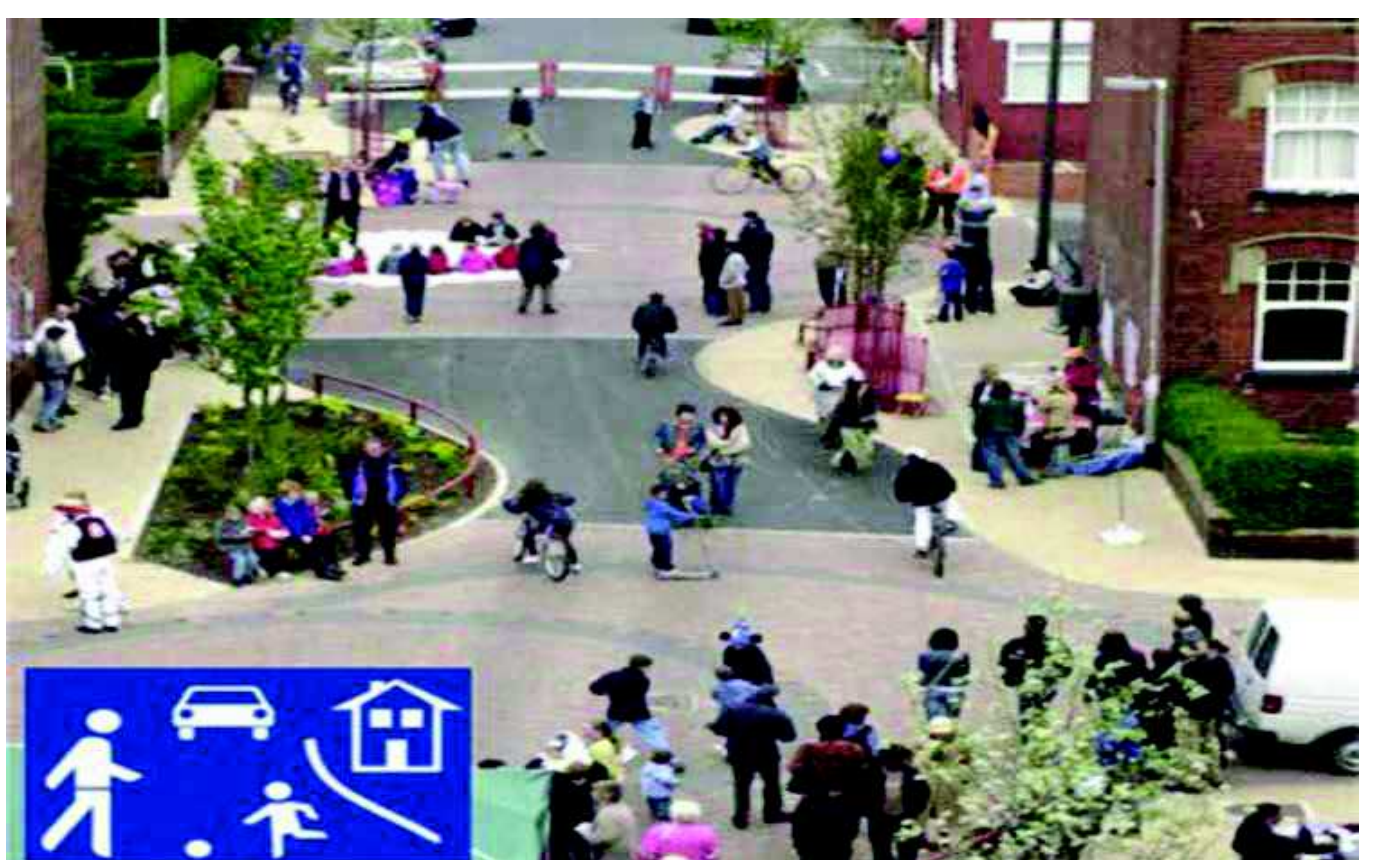

Figura 5 Woonerf, Londres, Inglaterra.

Fonte: Archinect.com. Disponível em: <http://la2b.org/2013/08/02/enforcement-engineering-action-planprogram-series/>. Acesso em: 26 set. 2015.

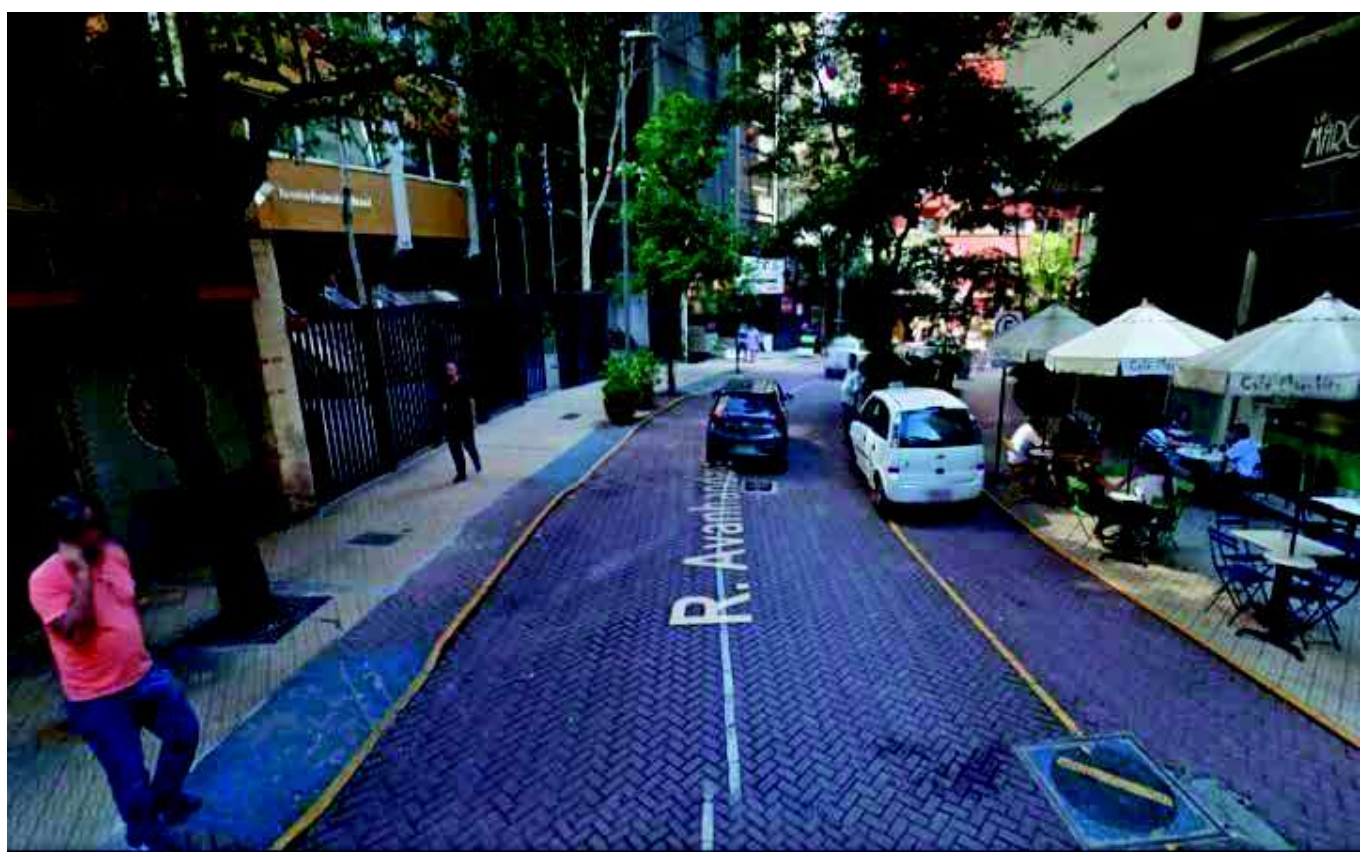

Figura 6 Rua Avanhandava, São Paulo, SP.

Fonte: Google Street View. Disponível em: <https://www.google.com.br/maps/@-23.54994,-

46.645192,3a,75y,154.74h,74.2t/data=!3m6!1 e1!3m4!1 sITg58s6hYh3ZK2opo 1WuWw!2e0!7i13312!8i6656>. Acesso em: 26 set. 2015 


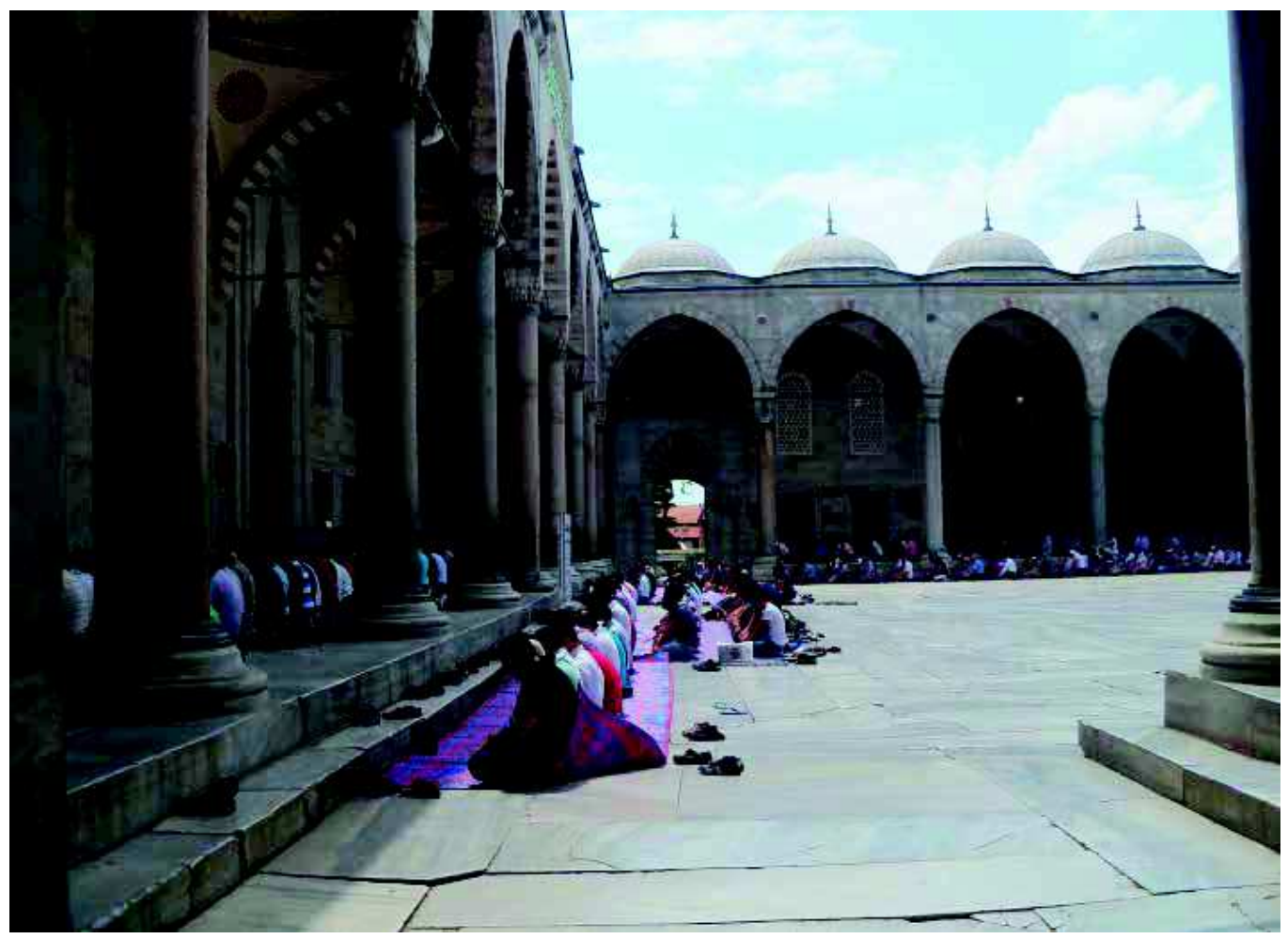

Figura 7 Pátio interno da Mesquita Azul, em Istambul, Turquia. Foto: Evy Hannes, jul. 2013.

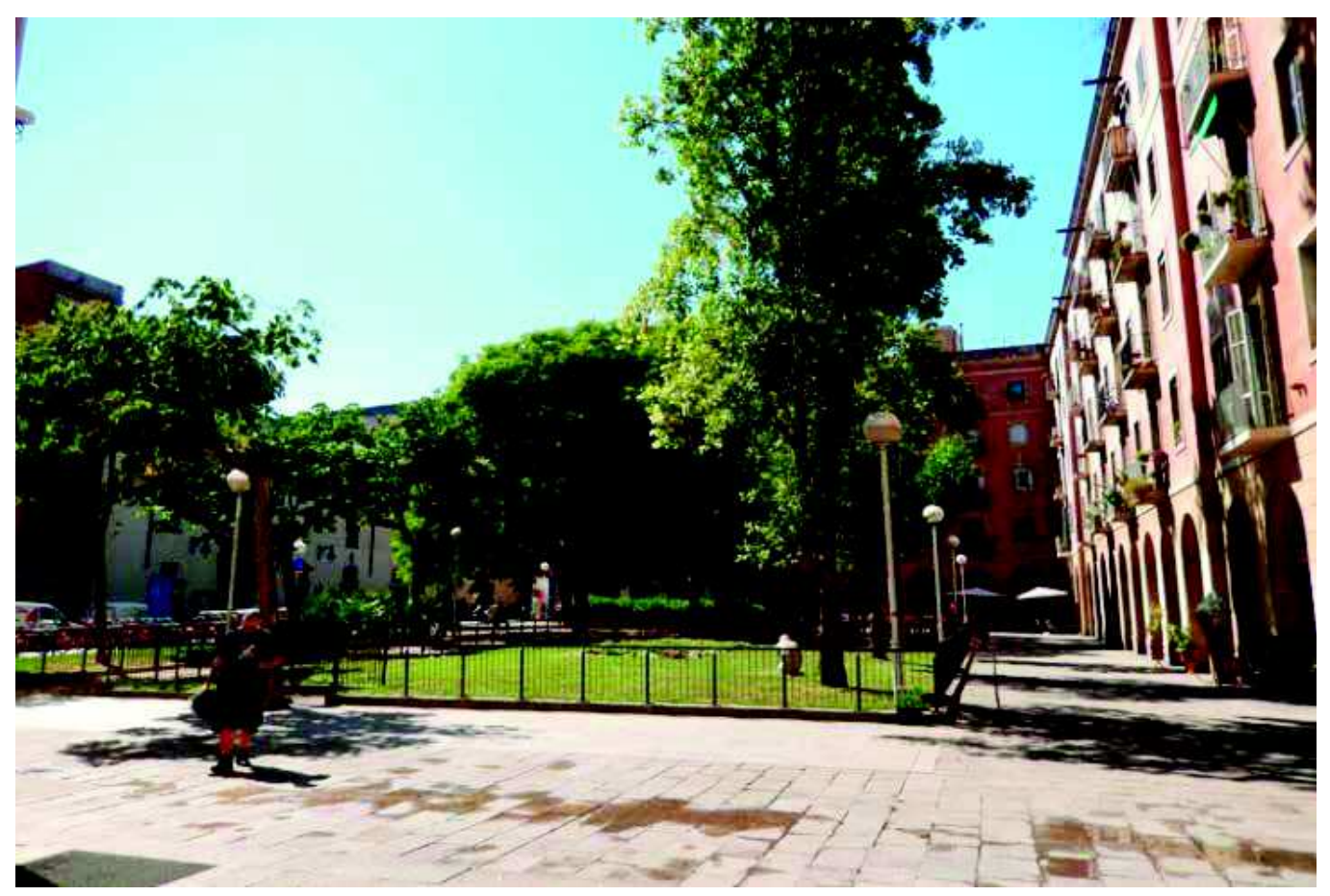

Figura 8 Pátio interno em quadra da cidade de Barcelona, Espanha. Foto: Evy Hannes, jul. 2014. 
No contexto urbano, os pátios, ou miolos de quadra, são muito usados e característicos da Europa, principalmente da cidade de Barcelona (Espanha). Foram previstos no Plano de Cerdá para a expansão da cidade, em 1859, por meio do qual todas as quadras deveriam apresentar centros livres que permitissem a travessia de pedestres (figura 8). A ideia de manter o miolo das quadras livres para o público não aconteceu como previsto devido aos interesses particulares dos moradores, e outros planos e incentivos do governo foram criados visando à abertura desses espaços para uso coletivo. Cullen, em análise sobre a paisagem urbana, entende o espaço do pátio como:

Síntese da polaridade entre pés e pneus, entre a circulação de pessoas e veículos. [...] Fora dele, o ruído e o ritmo apressado da comunicação impessoal [...] no interior, o sossego e a tranquilidade de sentir que o largo, a praça, ou o pátio tem escala humana. Lugar onde a luminosidade é atenuada, onde se fica apartado do burburinho da rua e se desfruta, simultaneamente, o exterior, de um ponto de observação bem situado e seguro". (CULLEN, 1983, p. 27).

A forma do pátio é fruto das paredes que o conformam e sua forma está estreitamente ligada à forma das quadras. Santos (1988) coloca-o como área non aedificandi, respiradouros onde os donos mantêm seus direitos de propriedade e como áreas utilizadas pela comunidade como bem de uso coletivo com funções diversificadas, garantindo vida, segurança e animação ao local.

Percebe-se que, de forma geral, os pátios apresentam três funções principais: nas edificações de caráter religioso, configuram-se como espaços de oração e meditação, apresentando forte caráter simbólico ligado ao jardim do Éden (paraíso), onde é possível estar em contato com o céu. Outra função importante liga-se ao conforto térmico: são locais que permitem ventilação dentro do bloco construído. A última delas, a que mais interessa para este trabalho, é a de lugares de encontro, espaços com caráter coletivo, onde acontecem trocas e tramas da vida cotidiana. Locais tranquilos, onde é possível parar, tomar café com amigos ou apenas sentar para descansar e observar o entorno. São espaços privados que transitam entre a esfera pública e a privada, portanto, de interesse coletivo e com grande diversidade de usos, sendo que estes determinarão - grau de constituição da esfera pública. Pátios ladeados por comércios e serviços possibilitam a constituição de uma esfera pública, enquanto pátios em meio a edifícios residenciais podem, no máximo, facilitar o acesso de pedestres entre quadras. Em ambos os casos, são espaços com grande potencial de enriquecimento para o ambiente urbano e a vida em sociedade.

\subsection{A PRAÇA}

A praça é o espaço público de encontro por excelência. Espaço urbano de convivência, permanência e lazer, acessível ao pedestre - e não aos veículos -, cercado pelos edifícios, os quais dão forma à mesma, compondo a estrutura e a identidade das cidades. Expressa os valores de uma civilização, sua história e seus ideais. Segundo 
Lamas (1993), a praça é um elemento das cidades ocidentais que se traduz na intencionalidade do desenho desses espaços: "[...] esta intencionalidade repousa na situação da praça na estrutura urbana, no seu desenho e nos elementos morfológicos (edifícios) que a caracterizam". O autor também fala sobre as seguintes implicações:

[...] estreita relação do vazio (espaço de permanência) com os edifícios, seus planos marginais e as fachadas. Estas definem os limites da praça e caracterizam-na, organizando o cenário urbano. A praça reúne a ênfase do desenho urbano como espaço coletivo de significação importante. Este é um dos seus atributos principais e que a distingue dos outros vazios da estrutura das cidades. (LAMAS, 1993, p. 102).

A praça originou-se da ágora grega, primeiro espaço de convívio público e cívico da sociedade - cercada por mercados, feiras livres, pelos edifícios públicos e governamentais mais importantes da época - onde se praticavam a democracia, os debates entre os cidadãos. (MACEDO; ROBBA, 2003). Na idade média, representa o principal espaço público, estando presente junto aos mercados, às prefeituras e igrejas, num momento em que seu desenho apresenta centro livre e conformado pelos edifícios do entorno. No renascimento, surgem as praças cívicas, rodeadas pelos principais edifícios públicos, adquirindo valores políticos e sociais (como na ágora grega), sendo adornadas com monumentos, obeliscos e estátuas. Nesse momento, têm-se as Piazzas Italianas como expoentes da expressão estética do espaço urbano; espaços secos, sem nenhuma vegetação e de intenso uso até hoje pelo público (figura 9). Em Londres, no século XVIII, surgem os Squares, jardins pequenos delimitados por edifícios residenciais que, com o passar do tempo, dão lugar a pequenas praças vegetadas e cercadas, de uso exclusivo da população local. No século XIX, algumas praças surgem como espaços decorrentes (residuais) de grandes intervenções no sistema viário, como as praças rotatórias de Paris, no Plano Haussmann, e as praças residuais das avenidas diagonais do Plano Cerdá em Barcelona. (LAMAS, 1993).

O urbanismo moderno propõe novas configurações de estruturação do território e das quadras, e a praça passa a ter papel secundário na criação do espaço. Nos séculos XX e XXI, a praça aparece dissociada dos edifícios e isolada no tecido urbano, trazendo caráter muito parecido com o das squares londrinas, assumindo no Brasil forte caráter de espaço vegetado de lazer e práticas esportivas.

Lugar de permanência e encontro, apropriado por artistas de rua, músicos, vendedores ambulantes, mesas e guarda-sóis de cafés e restaurantes, a praça representa o espaço de onde se pode observar a vida na cidade e perceber todo o encantamento (ou o oposto) dos acontecimentos sociais. Palco livre das manifestações humanas, também é frequentemente utilizada como local de embate e festividades.

As praças brasileiras apresentam papel de lugar de encontro com a natureza, já que assumem caráter voltado ao lazer, às práticas esportivas e à contemplação. Desde a pequena praça de bairro até as praças centrais, percebe-se o forte ecletismo e as influências francesas e americanas nas mais imponentes, ligadas aos grandes equipa- 
mentos públicos e áreas centrais, e influências inglesas nas praças voltadas às áreas residenciais, como se vê na figura 10. (MACEDO; ROBBA, 2003). A praça moderna, originada após a década de 1940, é fruto da escassez de espaços de lazer nas próprias residências, já que estas cederam lugar às garagens para automóveis. (MACEDO, 1999).

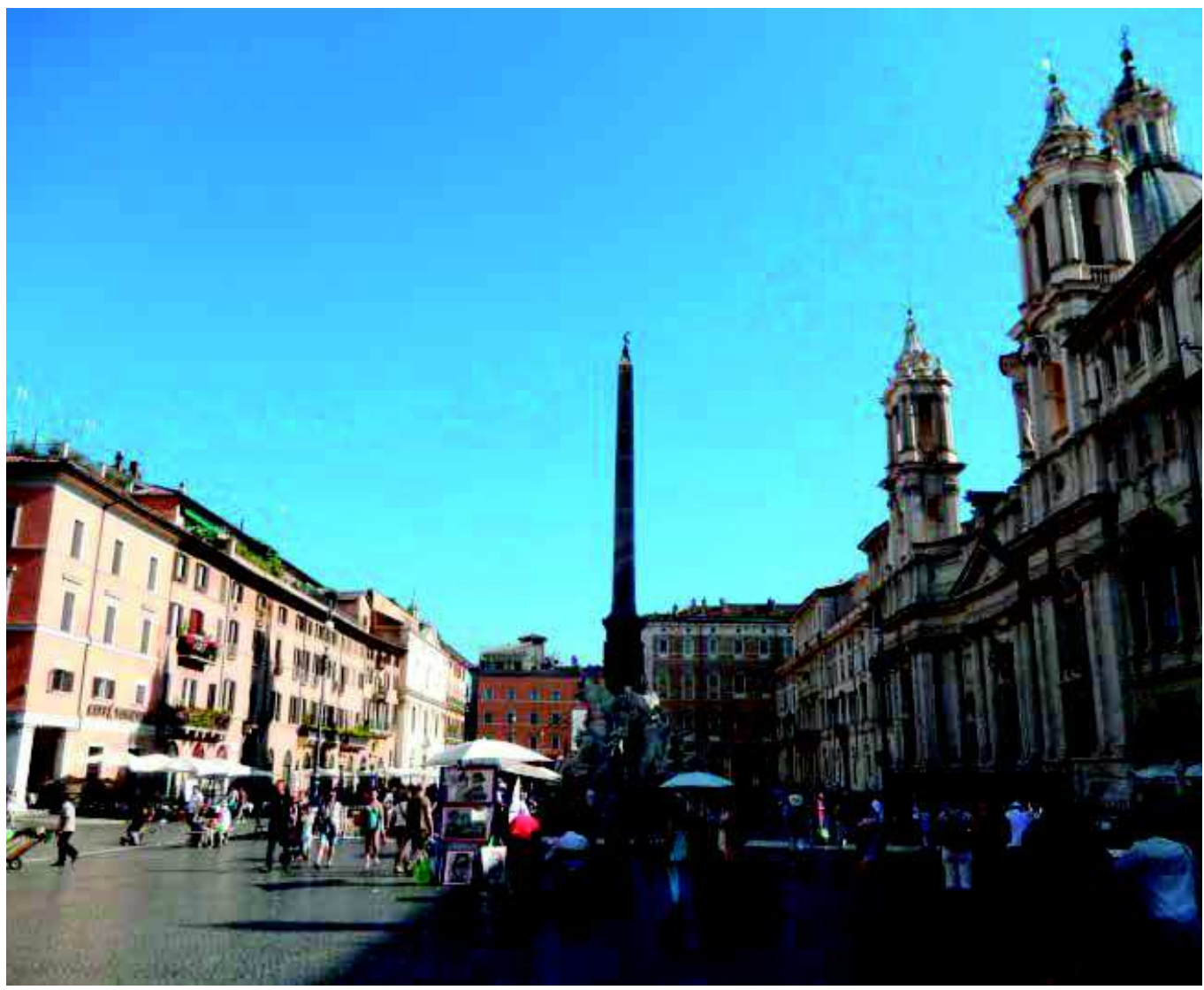

Figura 9 Piazza Navona, Roma, Itália.

Foto: Evy Hannes, jul. 2014.

Hoje muitas praças são originadas devido às normas de parcelamento do solo urbano, que ditam a necessidade de porcentagens específicas de áreas verdes e de lazer para novos loteamentos. Nesse caso, assumem caráter semelhante ao colocado por Macedo e Robba (2003), ficando sua produção a cargo de empresas de loteamento e incorporadores privados.

Dois tipos de espaços comumente associados às praças, mas que apresentam funções diferenciadas, são os adros e os largos. Os adros podem ser considerados os primeiros espaços livres públicos e constituem as áreas externas a edificações religiosas, com finalidade de reunir as pessoas antes das práticas religiosas e criar espaço livre, em frente à construção, que lhes confira caráter nobre e de grandeza arquitetônica. $\bigcirc$ largo é definido como um alargamento dos sistemas viários, com estreita relação com o traçado e a forma destes. Geralmente situados próximo a edifícios importantes, têm, também, função de abrir espaço à visualização do mesmo. 


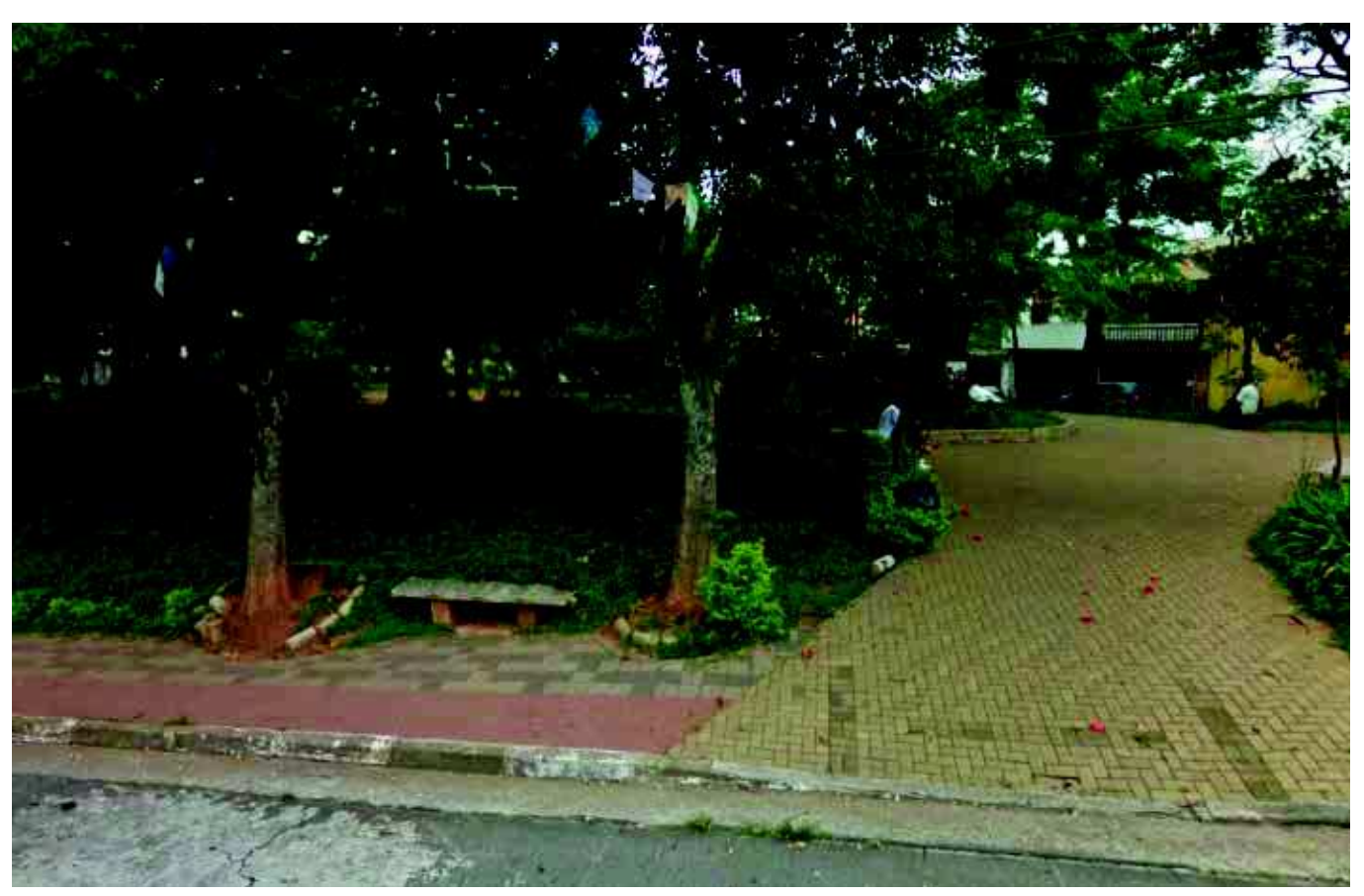

Figura 10 Praça Maurício Goulart, bairro Butantã, São Paulo, SP. Foto: Evy Hannes, ago. 2015.

\subsection{O POCKET PARK}

O conceito de pocket park (na tradução literal, parque de bolso) surgiu em 1967, em Nova lorque, com a criação do Paley Park (figura 11). A área onde havia uma casa noturna, com terreno de $13 \mathrm{~m} \times 30 \mathrm{~m}$, próximo à Quinta Avenida e no centro de Manhattan - onde o valor do metro quadrado está entre os mais caros do mundo -, deu lugar a um espaço verde, ao ar livre, de livre acesso à população, criando um tipo de espaço de interesse público inédito na história da arquitetura. (COOPER; FRANCIS, 1988).

Esse tipo de parque são pequenas áreas de lazer, ou miniparques, inseridas na malha urbana e que funcionam como pequenos oásis urbanos, onde é possível alcançar a tranquilidade mesmo em locais densos e de trânsito congestionado. $\bigcirc$ conceito previa a existência de cascatas que remetessem a questões da natureza e afastassem a polvição sonora da cidade, mobiliário leve, de fácil movimentação pelo público, máquinas de sanduíche e bebidas e fechamento noturno. Em relação ao desenho, podem apresentar desníveis desde que não configurem separação física e visual do espaço público e do passeio. Alguns possuem pergolados e coberturas que amenizam a insolação e protegem de ventos e chuvas.

Muitos espaços como esses foram criados pelo mundo: alguns alterando as características conceituais e dando origem a uma nova variedade de espaços de interesse público; outros, privados. Servem como áreas para pequenos eventos, parques infantis, áreas de encontro, áreas para lanches e cafés, sempre em pequenos lotes e com alcance apenas da escala local. São frutos de parcerias público-privadas, mantidos 
por organizações de bairro ou por comerciantes próximo ao local, que se beneficiam do seu uso (figura 12).

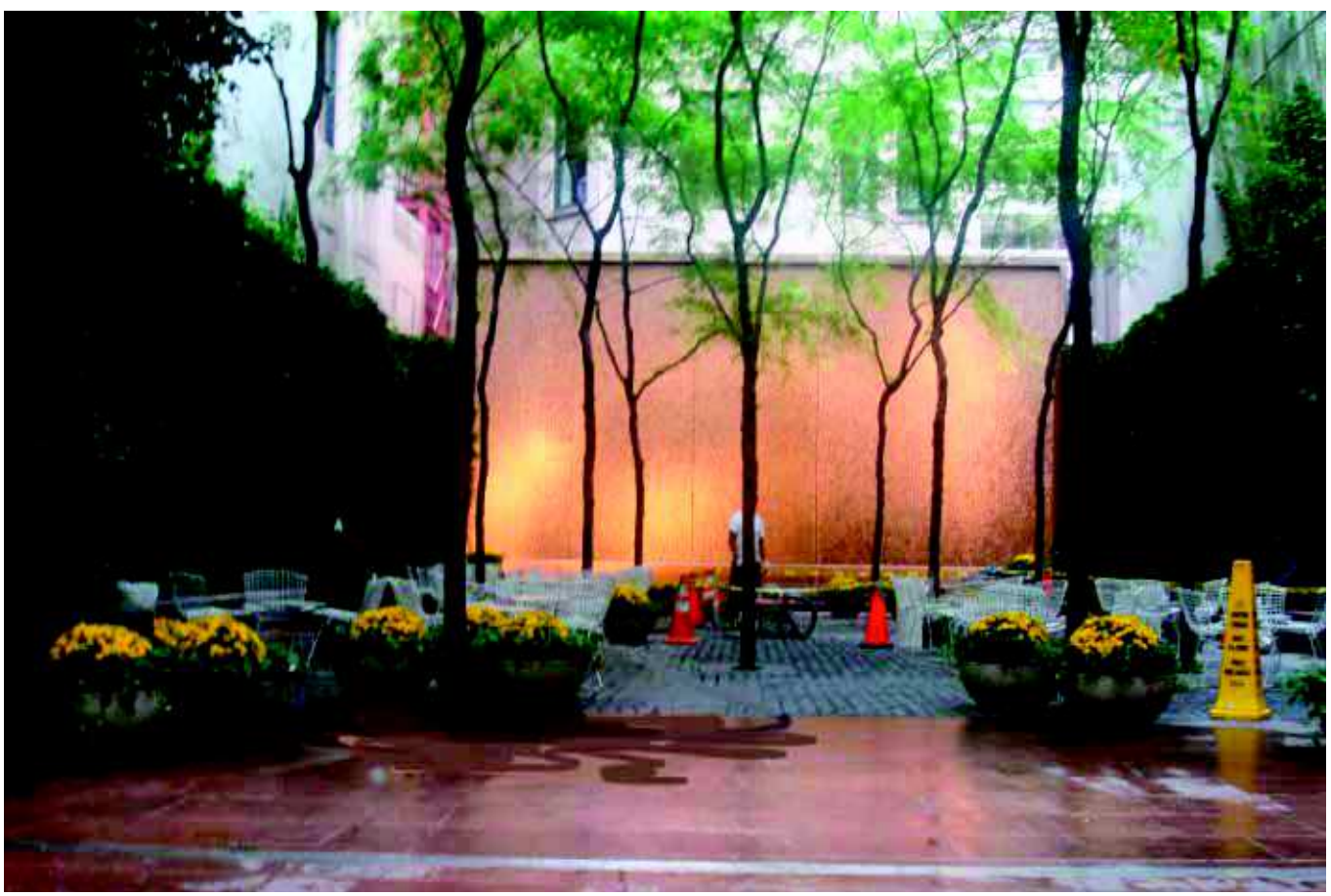

Figura 11 Palley Park, New York, USA.

Foto: Tatiana Daher Rocha, out. 2011.

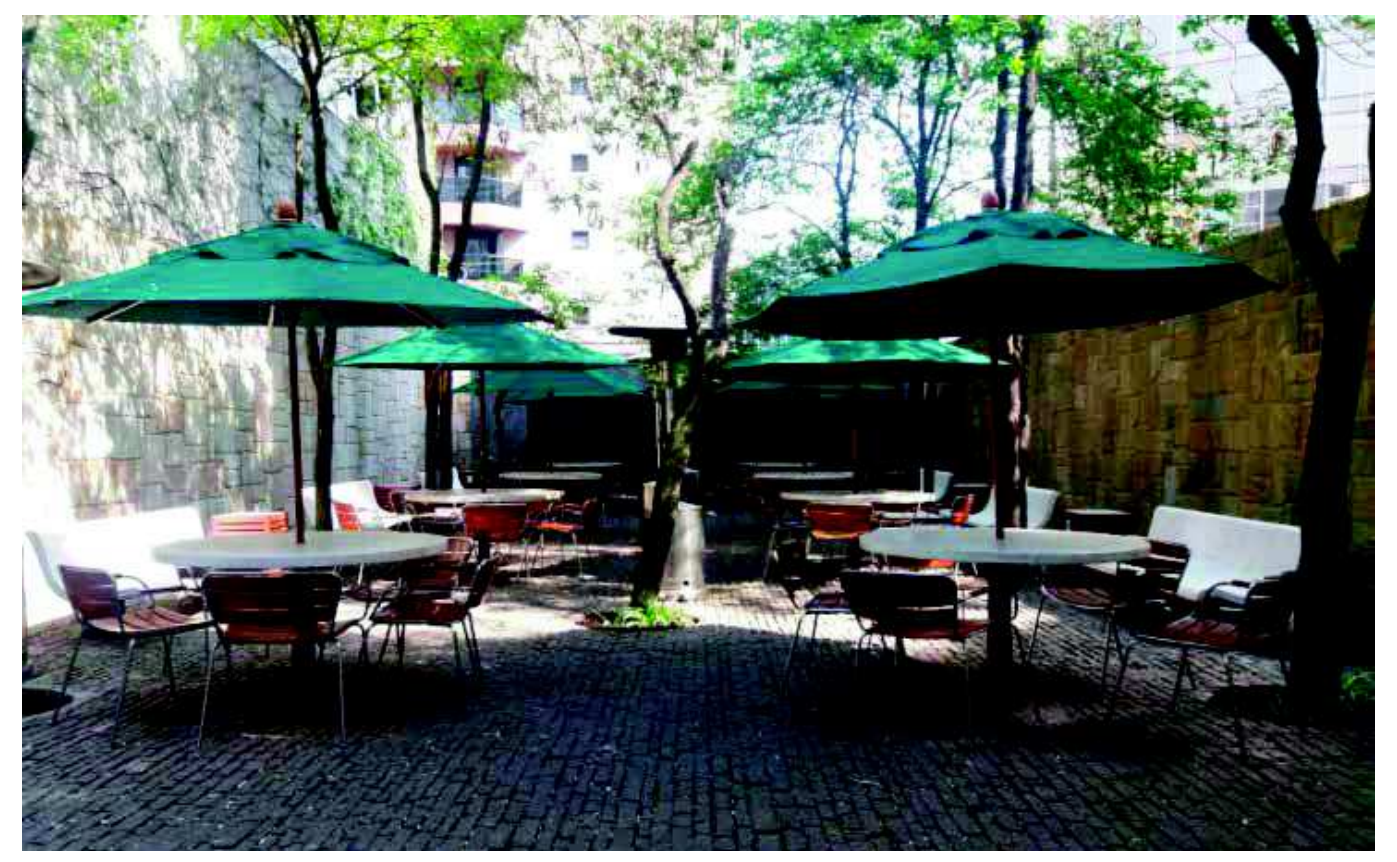

Figura 12 Pocket Park na rua Amauri, bairro do Itaim, São Paulo, SP. Foto: Evy Hannes, out. 2015. 
A importância do pocket park no contexto urbano se dá pela apropriação pública dos espaços livres, pela criação de áreas de descanso em meio a ambientes densamente urbanizados, como áreas de estar, pela oportunidade de permanência, por serem lugares protegidos, em que é possível ficar, fazer uma pausa, atender o telefone, checar um endereço, olhar um mapa ou cumprimentar um conhecido. Como bem apontado por Gehl:

Sempre que as pessoas param um pouco, elas procuram lugares no limite do espaço, um fenômeno que pode ser chamado de efeito dos espaços de transição. [...] esses espaços têm vários benefícios importantes: espaço à frente para ver tudo, as costas protegidas de modo que não surja nenhuma surpresa [...] e bom apoio físico e psicológico. (GEHL, 2013, p. 137).

\subsection{O PARQUE URBANO}

Existem variados tipos de parques e, na contemporaneidade, diversos complexos voltados ao lazer ganharam esse nome: parques de diversão, parques aquáticos, parque zoológico, parque ecológico e parque botânico, podendo ser públicos ou privados. De forma geral, pode-se dizer que parques são grandes áreas criadas para proteger áreas de interesse paisagístico e cultural, funcionando como espaço de recreação, esportes, turismo e contemplação da natureza. Este trabalho vai abordar o contexto do parque urbano, por ser o que mais se adequa ao recorte estudado, da escala do bairro à da cidade.

Segundo Kliass (1993), os parques urbanos são: "[...] espaços públicos com dimensões significativas e predominância de elementos naturais, principalmente cobertura vegetal, destinados à recreação." Macedo e Sakata o definem como:

Todo espaço de uso público destinado à recreação de massa, qualquer que seja o seu tipo, capaz de incorporar intenções de conservação e cuja estrutura morfológica é autossuficiente, isto é, não é diretamente influenciada em sua configuração por nenhuma estrutura construída em seu entorno. (MACEDO; SAKATA, 2003, p. 14).

Os mesmos autores o colocam como produto da era da cidade industrial. De fato, os parques surgiram na época da Revolução Industrial devido à necessidade de criar locais de lazer, recreação e contato com a natureza para a população, que vivia em condições insalubres e trabalhava em horários que muito excediam o comum nas fábricas inglesas. Para isso, a Coroa Inglesa abriu alguns dos jardins privados dos palácios para uso do público, criando o embrião do que se tornariam os parques urbanos. $\bigcirc$ Birkenhead Park foi o primeiro parque público projetado. Quem o projetou foi Joseph Paxton, em 1843. Na sequência, muitos parques foram criados em Londres, nos Estados Unidos e na Europa (figura 13). Nos Estados Unidos, surge uma figura de destaque na arquitetura paisagística, Frederick Law Olmsted, que cria parques e outros espaços 
únicos com inspiração na Escola Inglesa. $\bigcirc$ Central Park é um de seus projetos de maior visibilidade, criado com seu sócio, Calvert Vaux, em 1857. Olmsted introduz um novo conceito de paisagismo urbano, criando um espaço em larga escala, mas rico em pequenos detalhes. Dividido em áreas temáticas, foi pensado para ser visto de dentro para fora. (JELLICOE; JELLICOE, 1995).

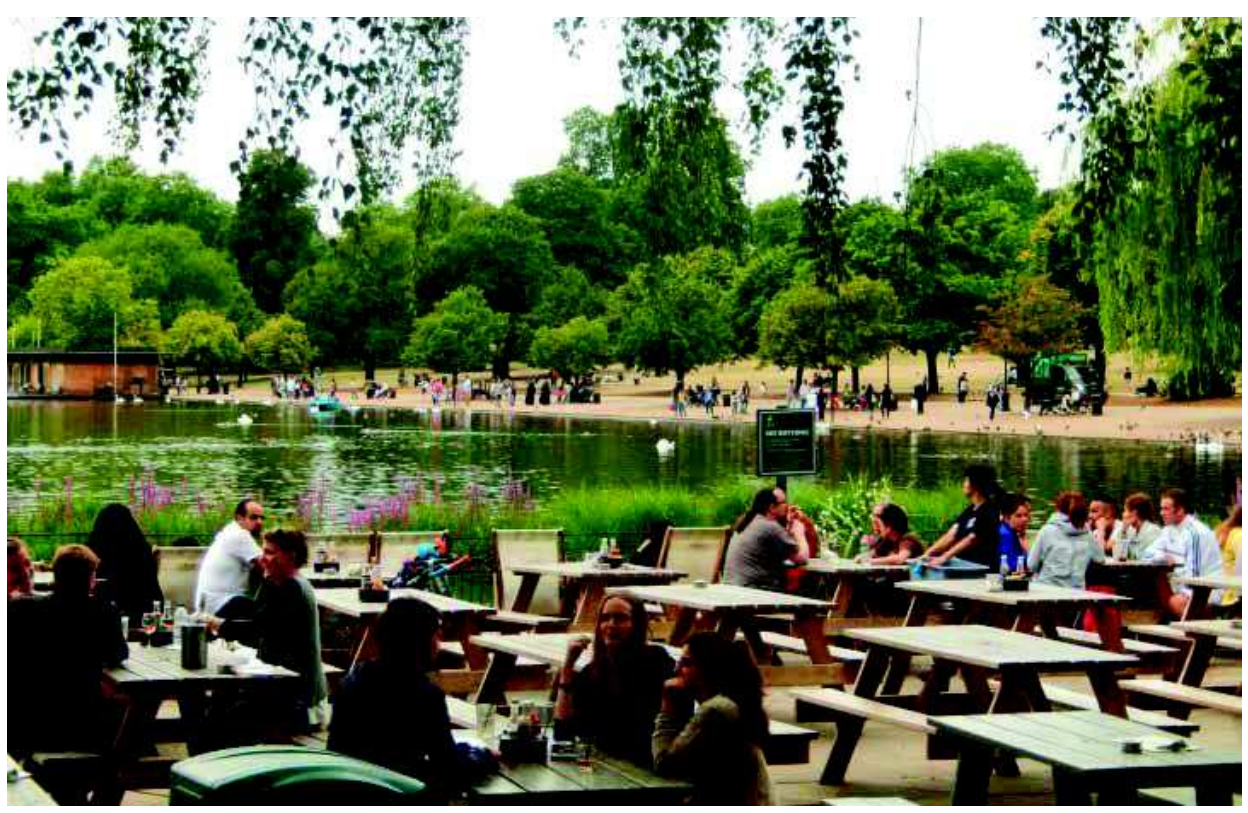

Figura 13 Hyde Park, Londres, Inglaterra. Foto: Evy Hannes, jul. 2014.

Os parques são estruturas independentes do entorno, possuindo, muitas vezes, acesso controlado e horários de abertura e fechamento determinados pelo seu mantenedor. Eles permitem o desenvolvimento de atividades diversas, desde a contemplação da paisagem até as mais variadas práticas esportivas, sendo estas livres, como uso de bicicletas, corridas e até as que se apoiam em equipamentos oferecidos pelo espaço, como pista de skate e quadras esportivas; possuem infraestrutura de apoio - administração, banheiros, depósitos e, às vezes, lanchonetes e lojas de souvenirs. Têm sido muito procurados e valorizados na contemporaneidade, especialmente nas grandes cidades-, nas quais se trabalha muito e os deslocamentos são longos -, onde as pessoas buscam qualidade de vida e espaços para relaxamento e práticas esportivas.

As cidades brasileiras apresentam grande número de belos projetos de parques urbanos, com grande variedade de estilos, notando-se predileção pelo estilo inglês. A cidade de Curitiba (PR) tem destaque nesse cenário, pois apresenta um sistema de parques bastante amplo, que compreende parques maiores e temáticos nas bordas da cidade e parques menores, de bairro; ao longo dos largos canteiros centrais das avenidas, há parques que fazem ligação com outros. Em São Paulo, o parque Ibirapuera ainda é o mais procurado pela população, devido à sua grande área e à oferta de atividades - mas outros parques têm surgido e chamado atenção pelo seu uso ou desenho. $\bigcirc$ 
parque do Povo, espaço em escala menor, tem sido muito usado por equipes de corrida que treinam no local, principalmente em horários diferenciados, como manhã e noite, antes e após o horário comercial. Já o parque da Juventude, desenvolvido no antigo espaço do complexo penitenciário do Carandiru, chama atenção devido ao belíssimo projeto paisagístico, desenvolvido pela arquiteta Rosa Kliass (figura 14).

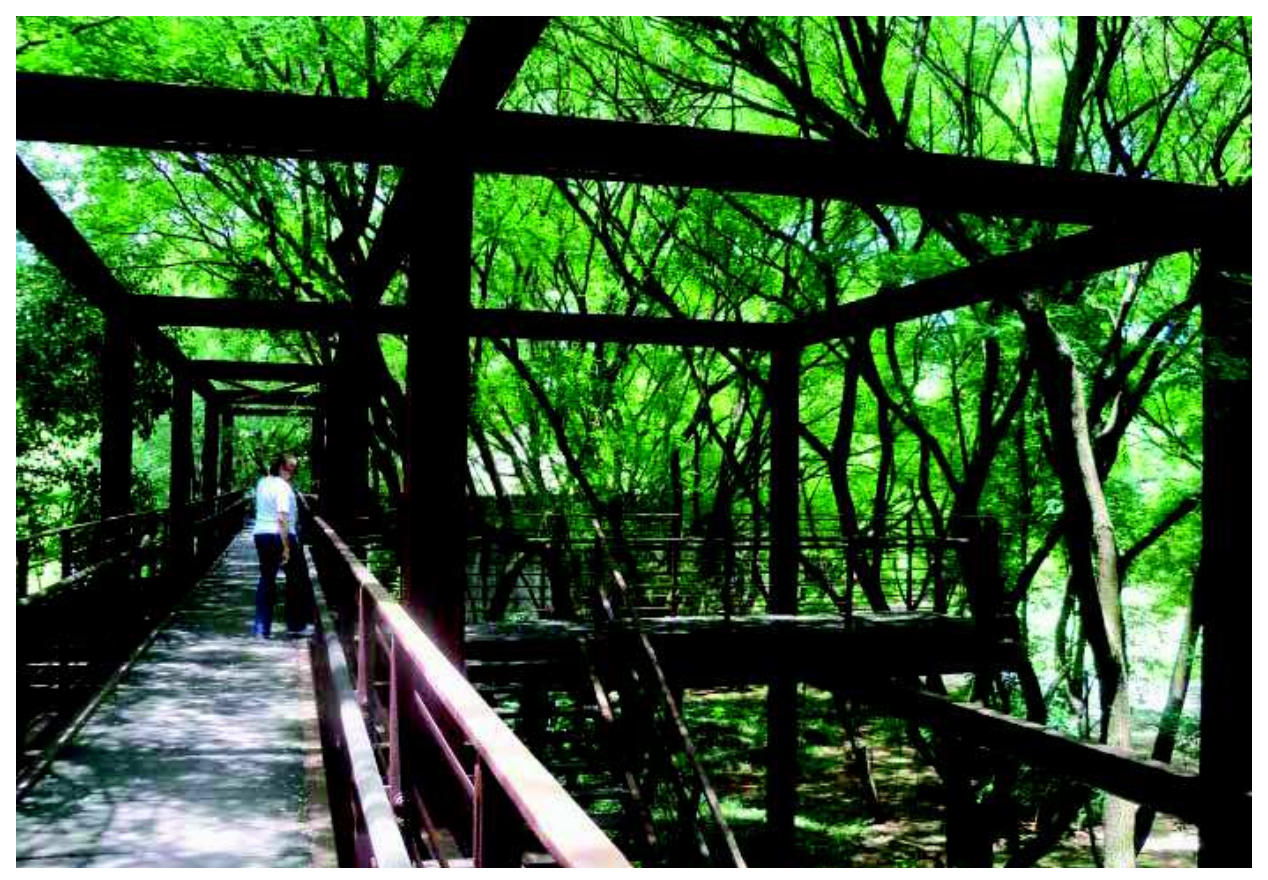

Figura 14 Trecho do "passeio da muralha" no parque da Juventude, São Paulo, SP. Foto: Evy Hannes, dez. 2010.

\subsection{ESPAÇOS INFORMAIS DE APROPRIAÇÃO PÚBLICA}

Por meio da observação do comportamento das pessoas, é possível perceber as mais interessantes formas de apropriação do espaço. Canteiros e muretas fazem papel de bancos; escadarias comportam-se como grandes salas de estar; espreguiçadeiras e sombrinhas ocupam áreas de caminhar, montando praias urbanas e áreas de piquenique (figuras 15, 16 e 17). $\bigcirc$ espaço livre é um grande palco para o desenrolar da vida e dos encontros da sociedade.

Nesse sentido, Queiroga (2001, p. 238) desenvolve o conceito de pracialidade, que categoriza espaços onde acontecem as funções que caracterizam o espaço da praça, como encontro e convívio social. $\bigcirc$ autor integra nessa categoria usos como manifestações em ruas e avenidas, jogos de futebol em espaços improvisados, praias urbanas.

É muito comum, nos últimos anos, com o aumento das questões ligadas a cuidados com a saúde e à qualidade de vida, ver canteiros centrais de avenidas sendo usados como pistas de cooper e corrida. Pracetas e espaços residuais do sistema viário tornam-se verdadeiras academias ao ar livre, onde personal trainers e esportistas estendem 
seus colchonetes e fazem alongamentos. Por ser fato intenso e presente no cotidiano, prefeituras implantaram, nos últimos cinco anos, equipamentos de ginástica ao ar livre em muitas praças e áreas residuais das cidades em todo o país. A mesma apropriação informal acontece nas calçadas mais lisas e corrimãos de escadas quando invadidos por skatistas (figuras 15 e 18) em busca de espaços que configurem obstáculos e pistas que propiciem manobras. Tais exemplos mostram a gama de possibilidades existente para apropriação dos espaços livres das cidades, seja em espaços desenhados para tais funções, ou naqueles que se apresentam como fruto das apropriações espontâneas da sociedade.

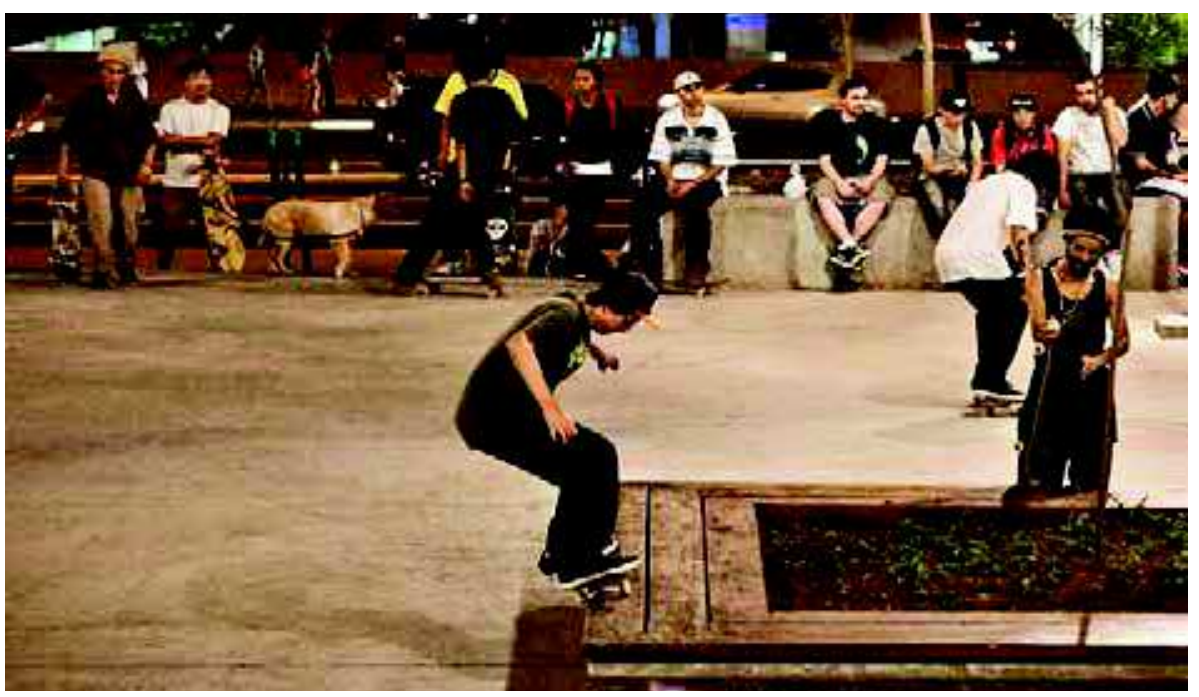

Figura 15 Skatista faz manobra sobre bancos da praça Roosevelt em São Paulo, SP, 2013.

Fonte: Folha de S. Paulo. Foto: Lucas Lima. Disponível em: <http://wwwl.folha.vol.com.br/

saopaulo/2013/09/1348192-um-ano-apos-reforma-praca-roosevelt-segue-na-preferencia-dos-skatistas.shtml> . Acesso em: 26 set. 2015.

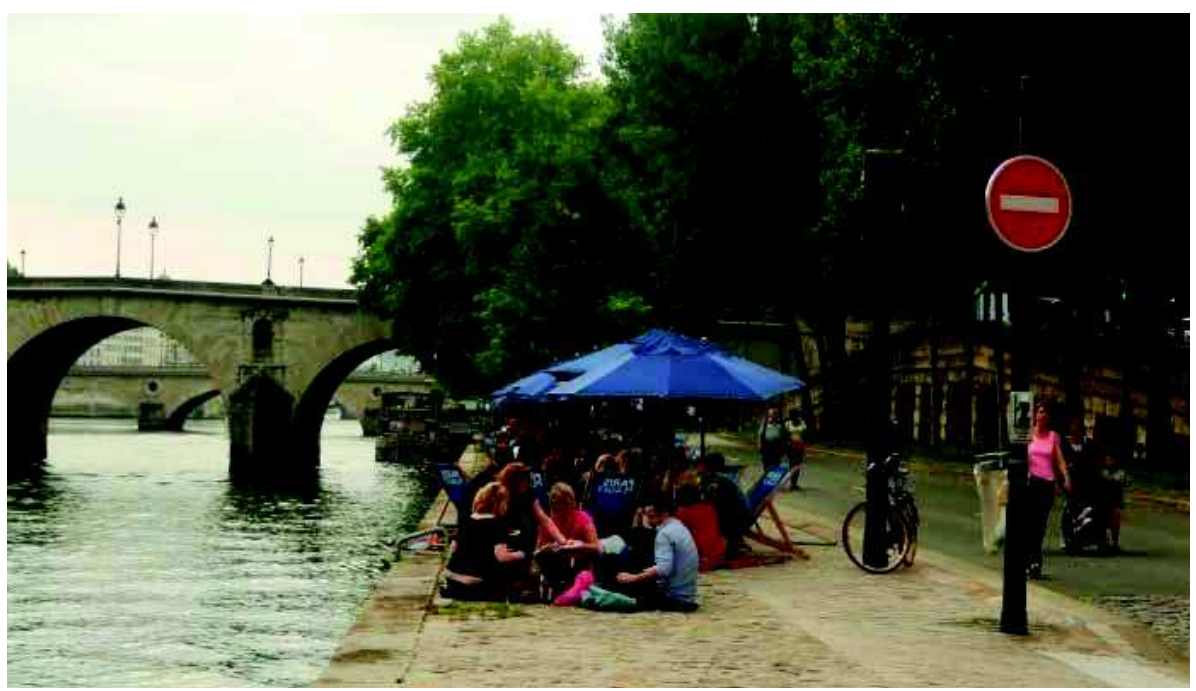

Figura 16 Piquenique em frente ao rio Sena, em Paris, França. Foto: Evy Hannes, jul. 2014. 


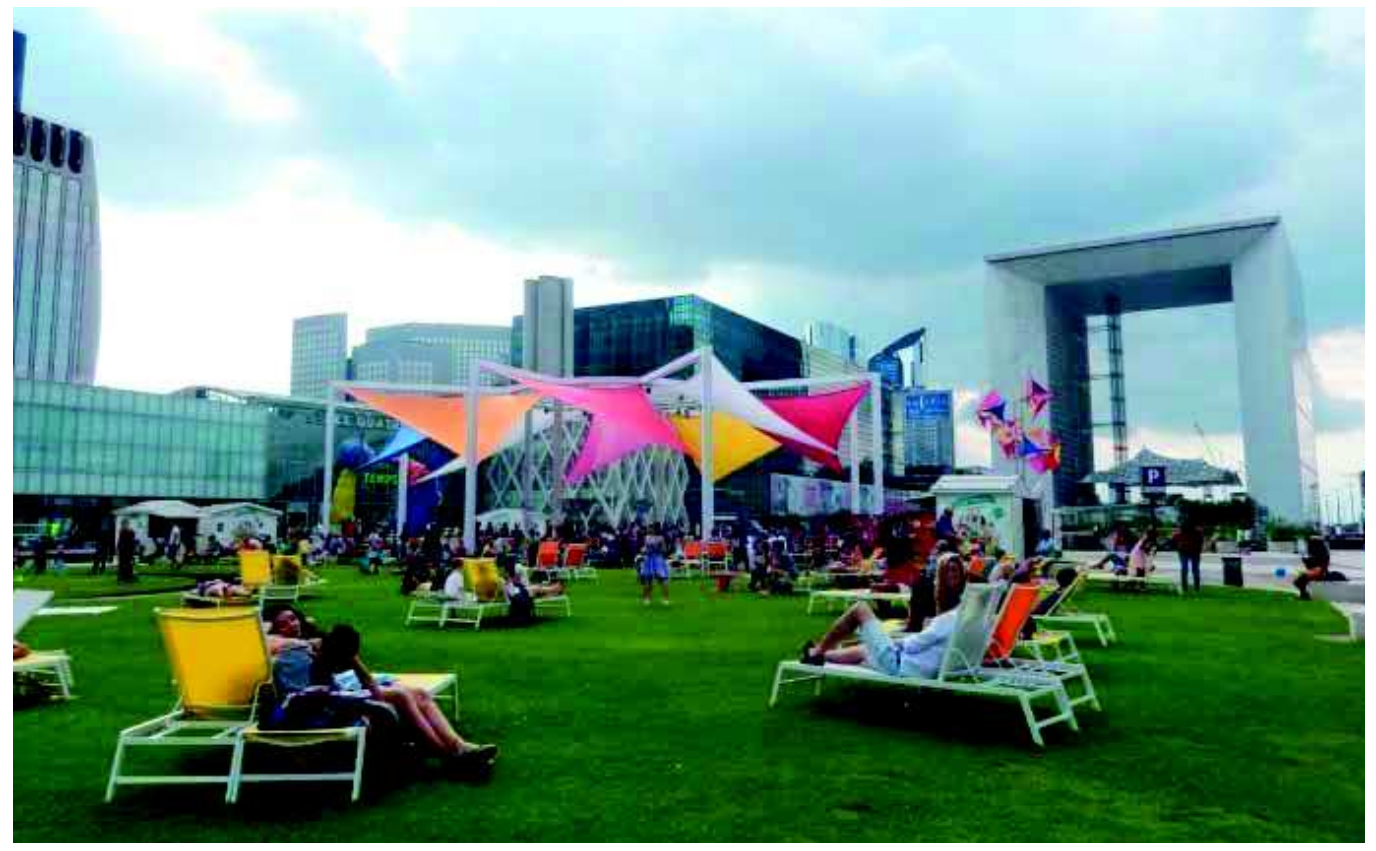

Figura 17 Praia urbana no bairro La Defense, em Paris, França. Foto: Evy Hannes, jul. 2014.

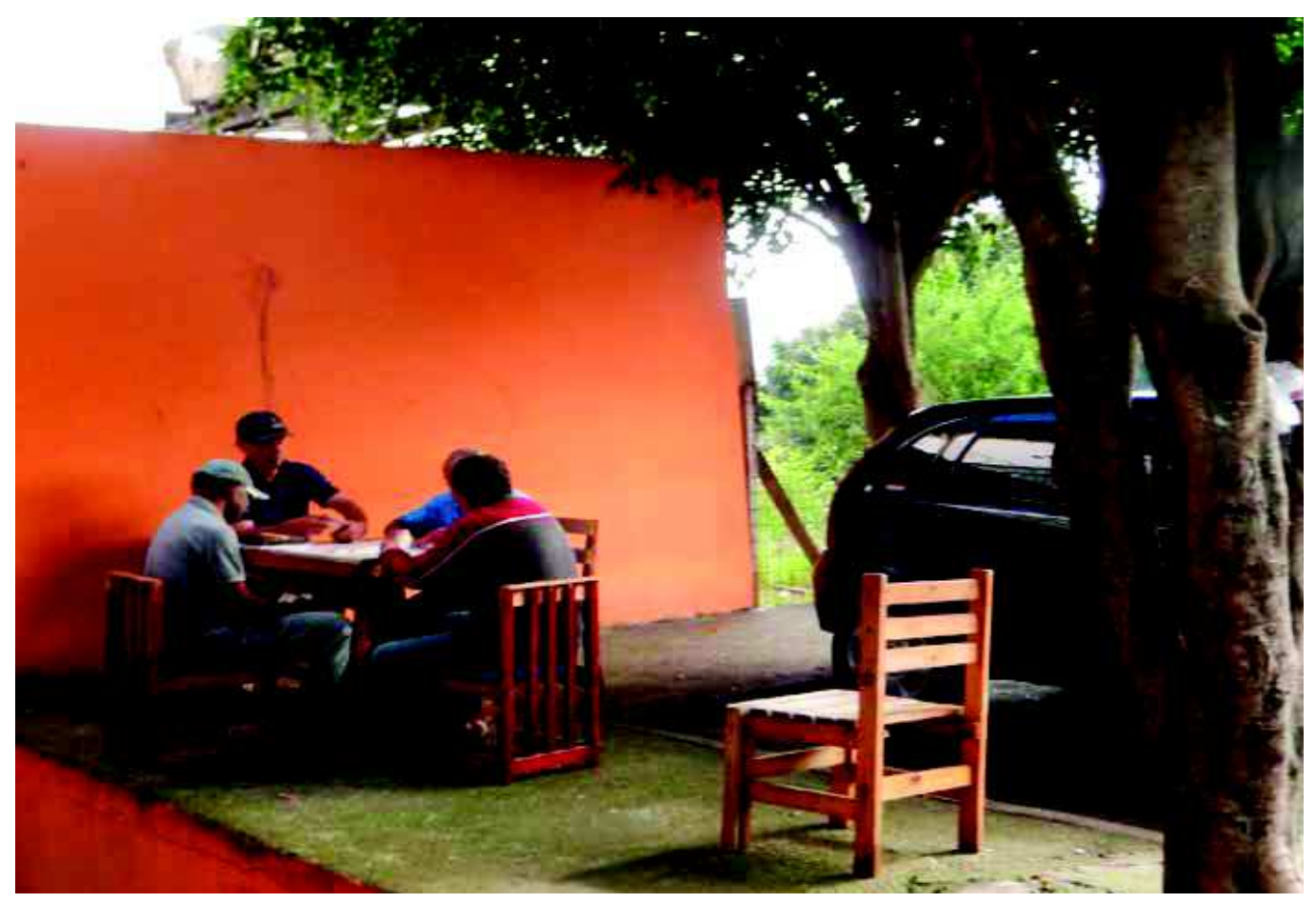

Figura 18 Moradores improvisam mesa de carteado sob sombra de árvore no bairro do Jaçanã, São Paulo, SP. Foto: Evy Hannes, abr. 2015. 


\section{CONSIDERAÇÕES FINAIS}

Este trabalho pretende criar corpo teórico referencial que funcione como base introdutória aos estudos sobre espaços livres, elencando e descrevendo as principais tipologias de espaço que podem ser utilizadas em intervenções na escala urbana da cidade. Não pretende desenvolver análise que simplifique ou resuma a complexidade e riqueza teórica relativa ao tema, mas que aborde, de forma clara, a variedade de interpretações e abordagens possíveis de desenvolvimento.

Os espaços livres estão presentes nas cidades desde os mais antigos assentamentos humanos, onde configuravam espaço de trocas comerciais. Com o passar do tempo, vêm se desenvolvendo conforme a evolução das cidades e os hábitos da sociedade, configurando novas tipologias de espaços abertos, como pocket parks e woonerfs, mais condizentes com as necessidades da sociedade e da cidade contemporânea. A apropriação dos espaços também apresenta mudanças, o que fica evidente quando canteiros centrais de avenidas passam a ser tomados por equipes de corrida.

Os elementos e tipos de espaço apresentados possuem caráter híbrido e exercem diferentes funções no contexto da cidade - urbanas, arquitetônicas, paisagísticas, estéticas, sociais - e são apropriados pelas pessoas das mais diversas formas. Mediante a utilização da rua como elemento articulador, compõem sistemas de espaços livres que estão presentes em todas as cidades, independentemente de seus tamanhos, apresentando características distintas de acordo com localização, clima e cultura específicos.

Cada tipologia discutida no texto desempenha um papel diferenciado no sistema de espaços livres da cidade, com inúmeras possibilidades de utilização e apropriação pelos pedestres, configurando a riqueza de experiências e as diferentes formas de expressão que podem ser realizadas nesses espaços fundamentais para o desenvolvimento da vida cotidiana, das relações sociais e da vida em comunidade. Espaços que ajudam a construir a cidadania e a memória afetiva dos habitantes com suas cidades.

\section{REFERÊNCIAS BIBLIOGRÁFICAS}

ARENDT, Hannah. A condição humana. Tradução de Roberto Raposo. 5 ed. Rio de Janeiro: Forense Universitária, 1991. (Publicação original: 1958).

COOPER, Marcus; FRANCIS, Carolyn. People places: design guidelines for urban open space. 2 ed. New York: John Wiley \& Sons, 1988. 367 p.

CULLEN, Gordon. Paisagem urbana. 2 ed. Lisboa: Edições 70, 1983. 202 p.

Enforcement + Engineering | action plan program series. LA/2B Staff, August 2, 2013. Disponível em: <https://la2b.org/2013/08/02/enforcement-engineering-action-plan-program-series/>. Acesso em: 26 set. 2015.

GEHL, Jan. Cidades para pessoas. 2 ed. São Paulo: Perspectiva, 2013. 262 p.

Guia Geográfico da Cidade de Curitiba. Disponível em: <http://curitiba.paises-america.com/bairros.htmconcursocultural-para-escolha-do-tema-da-proxima-edicao/>. Acesso em: 26 set. 2015.

Google Street View. Disponível em: <https://www.google.com.br/maps/@-23.5501051,-

46.645108,3a,75y, 154.74h,74.2t/data=!3m6!1e1!3m4!1slTg58s6hYh3ZK2opo1WuWw!2e0!7i13312!8i6656>. Acesso em: 26 set. 2015.

HABERMAS, Jürgen. Mudança estrutural da esfera pública: investigações quanto a uma categoria da sociedade burguesa. Rio de Janeiro: Tempo Brasileiro, 1984. 
JACOBS, Jane. Morte e vida das grandes cidades. São Paulo: Martins Fontes. 2000. 585 p.

JANUZZI, Denise de Cássia Rossetto. Calçadões: a revitalização urbana e a valorização das estruturas comerciais em áreas centrais. 2006. 318 f. Tese (Doutorado em Arquitetura e Urbanismo) - Faculdade de Arquitetura e Urbanismo da Universidade de São Paulo, São Paulo, 2006.

JELLICOE, Geoffrey; JELLICOE, Susan. 2 ed. The landscape of man. New York: Thames and Hudson Inc., 1995. $408 \mathrm{p}$.

KLIASS, Rosa Grena. Parques urbanos de São Paulo. São Paulo: Pini, 1993. 211 p.

LAMAS, José M. Morfologia urbana e desenho da cidade. Lisboa: Fundação Calouste Gulheran, 1993.590 p.

LEITE, Maria Angela Faggin Pereira. Um sistema de espaços livres para São Paulo. São Paulo: IEA-USP. Estudos Avançados, vol. 25, n 71 , abr. 2011, p.159-17.

LYNCH, Kevin. A imagem da cidade. São Paulo, Martins Fontes, 1997. 227 p.

MACEDO, Silvio Soares. Quadro do paisagismo no Brasil. São Paulo: Edusp, 1999. 144 p.

; ROBBA, Fábio. Praças brasileiras. 2 ed. São Paulo: Edusp, 2003. 312 p.

; SAKATA, Francine. Parques urbanos no Brasil. São Paulo: Edusp, 203. 207 p.

. et al. Sistemas de espaços livres privados - o outro lado do sistema de espaços livres urbanos: reflexões preliminares. In: MACEDO, Silvio Soares et al (Org.). Sistemas de espaços livres: conceitos, conflitos e paisagens. São Paulo: FAUUSP, 2011 , p. 33-53.

MAGNOLI, Miranda Martinelli. Projetos de Espaços Livres Urbanos. 1982. Tese (Pós-Doutorado em Arquitetura e Urbanismo) - Faculdade de Arquitetura e Urbanismo da Universidade de São Paulo, São Paulo, 1982.

Parada LGBT de São Paulo realiza concurso cultural para escolha do tema da próxima edição. Fashion Bubbles. Disponível em:<http://www.fashionbubbles.com/bubbles/parada-lgbt-de-sao-paulo-realiza-concurso-cultural-paraescolha-do-tema-da-proxima-edicao/>. Acesso em: 26 set. 2015.

QUEIROGA, Eugenio Fernandes. A megalópole e a praça: o espaço entre a razão de dominação e a ação comunicativa. São Paulo, 2001. 351 p. Tese (Doutorado em Arquitetura e Urbanismo) - Faculdade de Arquitetura e Urbanismo, Universidade de São Paulo, 2001.

Dimensões públicas do espaço contemporâneo: resistências e transformações de territórios, paisagens e lugares urbanos brasileiros. 2012. 284 f. Tese (Livre Docência em Arquitetura e Urbanismo) - Faculdade de Arquitetura e Urbanismo da Universidade de São Paulo, São Paulo, 2012.

. et al. Notas gerais sobre o Sistema de Espaços Livres da cidade brasileira. In: CAMPOS, A. et al (Org.) Sistemas de espaços livres: conceitos, conflitos e paisagens. São Paulo: FAUUSP, 201 1, p. 11-21.

SANTOS, Carlos Nelson Ferreira. A cidade como um jogo de cartas. Niterói: EDUFF, 1988. 192 p.

TURTELLI, Camila. Torneio resgata brincadeira de rua no centro de Ribeirão Preto. Folha de S. Paulo, 1 jun. 2014 Cotidiano. Disponível em: <http://wwwl folha.vol.com.br/cotidiano/ribeiraopreto/2014/06/1463244-torneioresgata-brincadeira-de-rua-no-centro-de-ribeirao-preto.shtml>. Acesso em: 26 set. 2015.

\section{AGRADECIMENTOS}

Agradeço aos professores Eugênio Fernandes Queiroga e Catharina Pinheiro Cordeiro dos Santos Lima por despertarem o interesse e estimularem o estudo sobre os espaços livres, acrescentando importante contribuição ao meu desenvolvimento profissional como docente e pesquisadora.

Nota do editor

Submissão: 13 jul. 2015

Aprovação: 19 out. 2015 